Bài báo khoa học

\title{
Đánh giá chất lượng nước mặt do ảnh hưởng của các hoạt động tại khu vực thành phố Cần Tho
}

\author{
Nguyễn Thành Tâm ${ }^{*}$, Trần Ngô Quốc Bảo ${ }^{2}$, Huỳnh Vương Thu Minh ${ }^{2}$, Nguyễn \\ Trường Thành ${ }^{2}$, Bùi Thị Bích Liên ${ }^{2}$, Nguyễn Đào Tuyết Minh ${ }^{1}$ \\ ${ }^{1}$ Viện Nghiên cứu Phát triển Đồng bằng sông Cửu Long, Trường Đại học Cần Thơ; \\ ngttam@ctu.edu.vn; minhB1811482@student.ctu.edu.vn \\ ${ }^{2}$ Khoa Môi trường \& Tài nguyên thiên nhiên, Trường Đại học Cần Thơ; \\ hvtminh@ctu.edu.vn; ntthanh@ctu.edu.vn; btblien@ctu.edu.vn; \\ baotran15101996@gmail.com \\ *Tác giả liên hệ: ngttam@ctu.edu.vn; Tel.: +84-909186071
}

Ban Biên tập nhận bài: 3/9/2021; Ngày phản biện xong: 23/10/2021; Ngày đăng bài: $25 / 1 / 2022$

Tóm tắt: Nguồn nước mặt ngày càng ô nhiễm do điều kiện tự nhiên và các hoạt động của con người. Chính vì thế, việc theo dõi, đánh giá và kiểm soát chất lượng nguồn nước mặt là nhiệm vụ quan trọng và cấp bách trong giai đoạn hiện nay. Nghiên cứu đã tiến hành thu thập số liệu chât lượng nước mặt giai đoạn 2000-2020 và khảo sát người dân ở các vùng xung quanh các nguồn thải: (i) khu dân cư (quận Ninh Kiều), (ii) khu công nghiệp (quận Bình Thủy), (iii) khu trồng cây ăn trái (huyện Phong Điền) và (iv) khu trồng lúa (quận Ồ Môn, Thới Lai và Cờ Đỏ). Kết quả nghiên cứu cho thấy các thời điểm lấy mẫu trong năm khác biệt không nhiều và có xu hướng xấu hơn ở tháng 12 , cụ thể $\mathrm{pH}$ và nhiệt độ không khác biệt giữa các khu vực nghiên cứu. Chất lượng nước mặt tốt nhất ở khu vực trồng cây ăn trái và xấu nhất ở khu vực dân cư. Nguyên nhân gây ô nhiễm nước mặt do có nhiều công ty, khu công nghiệp chưa xử lý chất thải tốt. Các chất thải được thải trực tiếp xuống sông ngày càng nhiều và do sử dụng quá nhiều phân bón và thuốc bảo vệ thực vật nên cần có biện pháp quản lý và xử lý tốt các nguồn thải trong thời gian tới.

Từ khóa: Khu dân cư; Khu công nghiệp; Khu trồng lúa; Các nguồn nước thải.

\section{Mở đầu}

Ô nhiễm nước mặt đã và đang là vấn đề nghiêm trọng đối với Việt Nam nói riêng và thế giới nói chung. Chính vì thế, trong thời gian qua đã có rất nhiều nghiên cứu nhằm tìm hiểu các nguyên nhân làm ảnh hưởng đến môi trường nước mặt. Trong đó, nghiên cứu về các quá trình tự nhiên và con người làm ảnh hưởng đến chất lượng nước mặt ở miền trung Bangladesh [1], hay đánh giá về chất lượng nước mặt ở Bắc Hy Lạp [2], nghiên cứu về sự thay đổi của chất lượng nước theo mùa vụ và địa điểm ở Thổ Nhĩ Kỳ [3],... Đặc biệt các tác giả còn nghiên cứu ảnh hưởng của hoạt động nông nghiệp đến chất lượng nước mặt [3-7], ảnh hưởng của khu công nghiệp đến chất lượng nước mặt [8-9] hay đô thị hóa làm ảnh hưởng đến chất lượng nước mặt [10]. Tuy nhiên, các nghiên cứu này được triển khai trên một hoặc hai hoạt động lên chất lượng nước mặt mà chưa so sánh giữa nhiều tác nhân với nhau.

Đối với Việt Nam, môi trường nước mặt là một vấn đề quan tâm hàng đầu của Chính phủ Việt Nam, chính quyền địa phương và cả dân cư [11-12] vì cuối cùng chất lượng nước mặt ảnh hưởng rất lớn đến sức khỏe đời sống của con người [13-14]. Trong đó bao gồm cả 
sức khỏe thể chất, lẫn sức khỏe tinh thần. Do tầm quan trọng của chất lượng nước mặt [14] nên quy chuẩn về chất lượng nước mặt đã được Chính phủ cập nhật thường xuyên trong thời gian qua. QCVN 08-MT:2015/BTNMT (QCVN 08) [15]. Năm 2020, Bộ Tài nguyên và Môi trường đã đưa ra dự thảo bổ sung thêm một số quy định về chất lượng môi trường nước [16]. Mặc dù sự quan tâm của các bên liên quan, nhưng chất lượng nước mặt hiện đang đối mặt với tình trạng ô nhiễm trầm trọng $[14,17]$ bởi sự gia tăng dân số quá nhanh, sự tăng trưởng ồ ạt của nền công nghiệp và sự đô thị hóa không kiểm soát của các thành phố lớn trong cả nước $[13,18]$ và do các hoạt động nông nghiệp gây ra. Sự ô nhiễm nguồn nước mặt có thể do nhiều nguồn khác nhau, trong đó, do ý thức của con người [19], do thiên tai và biến đổi khí hậu gây ra [14]. Các nghiên cứu về yếu tố ảnh hưởng đến chất lượng nước mặt đã được thực hiện [7, 18-21], nhưng đa phần các tác giả chỉ nghiên cứu một hoạt động làm ảnh hưởng đến chất lượng nước mặt như ảnh hưởng của khu công nghiệp, ảnh hưởng của dân cư, ảnh hưởng của trồng lúa đến chất lượng môi trường nước mặt. Chưa có nhiều nghiên cứu so sánh nhiều yếu tố tác động làm ảnh hưởng đến chất lượng nước mặt, trong đó cụ thể là tại thành phố Cần Thơ (TPCT). Trong bối cảnh đó, cần có cái nhìn tổng quát về diê̂n biến của chất lượng nước mặt và nguồn gây ô nhiễm trong một thời gian dài qua các số liệu thu thập, quan trắc hàng năm, kết hợp với sự đánh giá thực tế và cảm nhận thực tế về chất lượng nguồn nước đã thay đổi như thế nào trong khoảng thời gian 20 năm qua. Nghiên cứu đã tiến hành thu thập số liệu thứ cấp về chất lượng nguồn nước mặt ở TPCT giai đoạn 2000-2020 về các chỉ tiêu lý hóa của nước tương tự nghiên cứu của [21] và kết hợp với phương pháp phỏng vấn nông hộ trên địa bàn TPCT. Nghiên cứu chọn địa bàn TPCT làm vùng nghiên cứu vì đây là vùng giữa nguồn sông Mê Công và có đầy đủ các hoạt động làm ảnh hưởng đến chất lượng nguồn nước mặt như trồng lúa, trồng cây ăn trái, các khu công nghiệp và có mật độ dân cư tập trung cao ở các khu vực trung tâm của thành phố. Mục tiêu của nghiên cứu này nhằm xác định xem các yếu tố nào ảnh hưởng chính đến chất lượng nước mặt và diễn biến của chất lượng nước mặt như thế nào trong 20 năm qua tại TPCT.

\section{Phương pháp nghiên cứu}

\section{1. Đối tượng và khu vực nghiên cứu}

Nghiên cứu này đã thực hiện đánh giá và khảo sát quan điểm của người dân về chất lượng môi trường nước mặt tại TPCT ở 4 khu vực có các hoạt động làm ảnh hưởng đến chất lượng nguồn nước mặt như: (1) Khu vực dân cư; (2) Khu công nghiệp; (3) Khu vực trồng cây ăn trái và (4) Khu vực trồng lúa tại TPCT. Chi tiết về vị trí quan trắc chất lượng nước được thể hiện qua Hình 1 .

\subsection{Phuơng pháp thu thập số liệu}

\subsubsection{Số liệu thứ cấp}

Các số liệu thứ cấp về chất lượng nguồn nước mặt được thu thập tại Trung tâm Quan trắc Tài nguyên và Môi trường - Sở Tài nguyên và Môi trường TPCT về các chỉ tiêu: nhiệt độ, $\mathrm{pH}$, nhu cầu oxy sinh hóa $\left(\mathrm{BOD}_{5}\right)$, nhu cầu oxy hóa học $(\mathrm{COD})$, oxy hòa tan $(\mathrm{DO})$, amoni $\left(\mathrm{NH}_{4}{ }^{+}\right)$, tổng chất rắn lơ lửng (TSS), nitrit $\left(\mathrm{NO}_{2}^{-}\right)$, nitrat $\left(\mathrm{NO}_{3}{ }^{-}\right)$và $\mathrm{PO}_{4}{ }^{3-}$ trong giai đoạn 20 năm từ năm 2000 đến 2020 vào các tháng $3,6,9$ và 12 hàng năm tại 20 địa điểm nghiên cứu thuộc 4 vùng nghiên cứu khác nhau (Hình 1).

\subsubsection{Số liệu sơ cấp}

Số liệu sơ cấp được thực hiện bằng phương pháp điều tra nông hộ theo biểu câu hỏi soạn sẵn và theo phương pháp thuận tiện ngẫu nhiên theo 4 vùng nghiên cứu thuộc địa bàn TPCT. Cỡ mẫu thu thập cho tổng khu vực nghiên cứu là 145 mẫu. Các chỉ tiêu thu thập về: khảo sát về nguồn nước cung cấp cho các mục đích sử dụng nước, các biện pháp xử lý trước khi thải 
ra nguồn tiếp nhận, đánh giá nhận thức của người dân về môi trường nước, các nguyên nhân và giải pháp khắc phục.

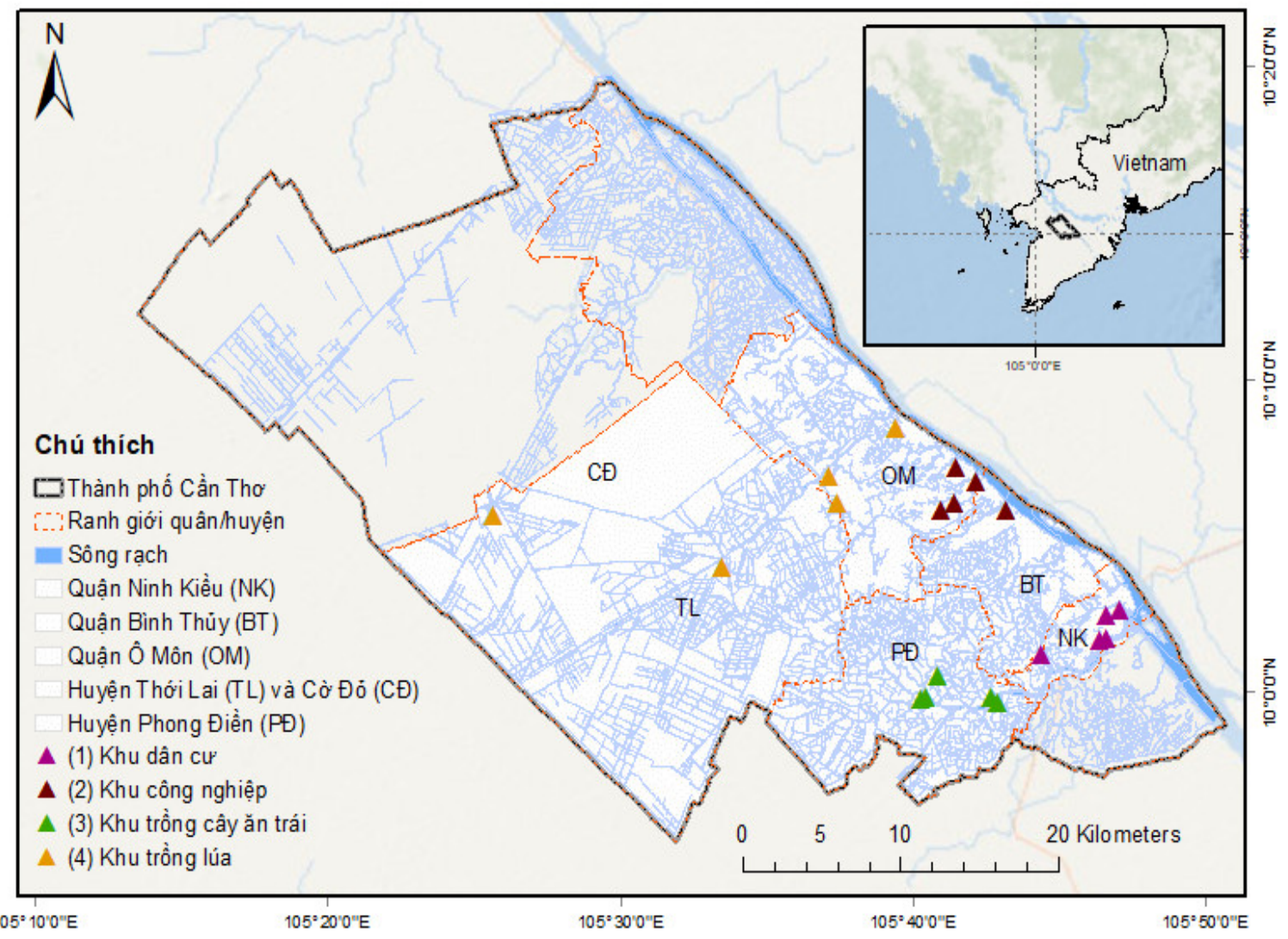

Hình 1. Vị trí các điểm quan trắc chất lượng nước tại TPCT giai đoạn 2000-2020.

\subsection{Phương pháp xủ lý số liệu}

Sử dụng phương pháp thống kê mô tả để mô tả các thông số về chất lượng nước mặt và các số liệu khảo sát tại vùng nghiên cứu.

Sử dụng phương pháp phân tích phương sai ANOVA và phép thử DUNCAN để so sánh chất lượng nước mặt tại các vùng nghiên cứu khác nhau (vùng sản xuất lúa, vùng trồng cây ăn trái, vùng dân cư, khu công nghiệp).

Sử dụng Quy chuẩn quốc gia (QCVN 08-MT:2015/BTNMT) về chất lượng nước mặt để so sánh và đối chiếu với chất lượng nước mặt tại TPCT.

Sử dụng phương pháp phân tích tương quan để xác định sự tương quan giữa các chỉ tiêu chất lượng nước và theo tiến độ thời gian (năm).

\section{Kết quả và thảo luận}

\subsection{Kết quả nghiên cưu chất lượng nước mặt tại TPCT giai đoạn 2000-2020}

\subsubsection{Kết quả chất lượng nước mặt theo khu vực nghiên cứu}

Kết quả phân tích thống kê Bảng 1 cho thấy, có 8 chỉ tiêu có sự khác biệt ý nghĩa thống kê về chất lượng giữa 4 khu vực nghiên cứu như: $\mathrm{DO}, \mathrm{BOD}_{5}, \mathrm{COD}, \mathrm{TSS}, \mathrm{NH}_{4}^{+}, \mathrm{Fe}, \mathrm{NO}_{2}^{-}$và $\mathrm{NO}_{3}{ }^{-}$ở mức ý nghĩa thống kê $1 \%$. Các chỉ tiêu về $\mathrm{pH}$, nhiệt độ và $\mathrm{PO}_{4}{ }^{3-}$ khác biệt không ý nghĩa ở mức 5\%.

Giá trị pH trung bình giữa 4 khu vực nghiên cứu trong giai đoạn 20 năm đạt 7,09 và dao động từ 7,07 (khu vực dân cư) đến 7,14 (khu công nghiệp). Nhìn chung giá trị pH của địa 
bàn TPCT đạt mức A1 theo QCVN 08-MT:2015/BTNMT (Hình 2), điều này cho thấy giá trị $\mathrm{pH}$ phù hợp cho các động vật thủy sinh và các mục đích sử dụng khác.

Nhiệt độ nước trung bình ở tất cả các địa điểm đạt $27,2^{\circ} \mathrm{C}$ và sự khác biệt không có ý nghĩa ở mức ý nghĩa thống kê $5 \%$ ở 4 khu vực. Do khu vực nghiên cứu hoàn toàn trong phạm vi TPCT và nền nhiệt không khí tương đối đồng đều nên nhiệt độ nước ở các khu vực nghiên cứu không khác biệt.

Chỉ tiêu hàm lượng oxy hòa tan $(\mathrm{DO})$ có sự khác biệt giữa bốn khu vực nghiên cứu ở mức ý nghĩa $1 \%$. Trung bình hàm lượng oxy hòa tan đạt $4,6 \mathrm{mg} / \mathrm{L}$. Khu vực Khu công nghiệp có hàm lượng $\mathrm{DO}$ cao nhất $(4,8 \mathrm{mg} / \mathrm{L})$ và khác biệt có ý nghĩa so với 3 khu vực còn lại. Trong khi đó, hàm lượng DO thấp nhất ở Khu dân cư $(4,4 \mathrm{mg} / \mathrm{L})$. DO cao hơn có thể cho thấy khả năng tự làm sạch của các vùng nước tốt hơn. Tuy nhiên, giá trị oxy hòa tan đo được tại khu vực nghiên cứu tương đối thấp, do đó có thể gây ra sự thiếu hụt cho các thủy sinh vật, cụ thể chỉ đạt cột B1 theo quy chuẩn QCVN 08-MT:2015/BTNMT, có thể phục vụ tưới tiêu hoặc thủy lợi (Hình 2). DO ở các vùng nước mặt tại Cần Thơ không thực sự thích hợp đối với đời sống thủy sinh [24]. Từ số liệu chất lượng nước cho thấy DO thấp là do ô nhiễm bởi các chất hữu cơ.

Hàm lượng COD cao nhất ở khu dân cư $(18,8 \mathrm{mg} / \mathrm{L})$ và khác biệt ý nghĩa so với các khu vực còn lại. Trong khi, 3 khu vực còn lại có hàm lượng COD không khác biệt thống kê, bên cạnh đó khu vực trồng cây ăn trái có khuynh hướng có hàm lượng COD thấp nhất $(12,6$ $\mathrm{mg} / \mathrm{L}$ ). Trung bình hàm lượng COD của $4 \mathrm{khu}$ vực nghiên cứu là $15,1 \mathrm{mg} / \mathrm{L}$. Xét tổng thể, trung bình hàm lượng $\mathrm{COD}$ của tất cả các khu vực nghiên cứu đạt mức $\mathrm{B} 1$. Tuy nhiên, nếu đánh giá theo khu vực thì chỉ có khu vực dân cư có hàm lượng $\mathrm{COD}$ ở mức $\mathrm{B} 1$, các khu vực còn lại đạt mức A2 theo QCVN 08-MT:2015/BTNMT (Hình 2). Ở sông Hậu, COD dao động từ $11,68 \pm 3,76-13,54 \pm 4,72 \mathrm{mg} / \mathrm{L}$ [23] được coi là giàu dinh dưỡng [25]. Trong nghiên cứu này, $\mathrm{COD}$ chỉ ra rằng các thủy vực ở khu vực nghiên cứu ở mức trung bình, cho thấy chất lượng nước có dấu hiệu bị ô nhiềm. Kết quả này phù hợp với nghiên cứu về chất lượng nước mặt ở quận Ninh Kiều trong hai năm 2018 và 2019 [22].

Hàm lượng $\mathrm{BOD}_{5}$ trung bình của các khu vực nghiên cứu đạt $9,4 \mathrm{mg} / \mathrm{L}$, giá trị này đạt mức B1 của QCVN 08-MT:2015/BTNMT (Hình 2). Cụ thể, hàm lượng $\mathrm{BOD}_{5}$ đạt giá trị nhỏ nhất ở khu vực trồng cây ăn trái $(7,8 \mathrm{mg} / \mathrm{L})$. Trong khi đó, hàm lượng $\mathrm{BOD}_{5}$ cao nhất hay xấu nhất đối với chất lượng nước khu vực nghiên cứu là khu dân cư $(11,4 \mathrm{mg} / \mathrm{L})$. Qua kết quả $\mathrm{BOD}_{5}$ cho thấy, tại khu dân cư, các chất ô nhiễm dạng dễ phân hủy sinh học nhiều hơn và chất lượng nước mặt thấp hơn khu vực trồng cây ăn trái.

Các nghiên cứu trước đây cho thấy nồng độ $\mathrm{BOD}_{5}$ trong các thủy vực ở tỉnh An Giang là $6,6 \pm 1,2-8,2 \pm 2,5 \mathrm{mg} / \mathrm{L}$ [26] và ở tỉnh Sóc Trăng là $2,2-22,4 \mathrm{mg} / \mathrm{L}$ [27]. $\mathrm{BOD}_{5}$ và $\mathrm{COD}$ là các thông số chất lượng nước có thể chỉ ra các chất ô nhiễm hữu cơ [28] có nguồn gốc từ chăn nuôi, bãi chôn lấp, sinh hoạt, dịch vụ và các hoạt động khác [29].

Xét về chỉ tiêu tổng chất rắn lơ lửng trong nước (TSS), kết quả Bảng 1 cho thấy trung bình TSS của $4 \mathrm{khu}$ vực là $39,7 \mathrm{mg} / \mathrm{L}$ và dao động từ $35,6-45,1 \mathrm{mg} / \mathrm{L}$. Trong nghiên cứu này, tổng chất rắn lơ lửng đối với khu vực trồng cây ăn trái là cao nhất $(45,1 \mathrm{mg} / \mathrm{L})$, khác biệt ý nghĩa so với khu dân cư $(35,6 \mathrm{mg} / \mathrm{L})$, nhưng không khác biệt ý nghĩa so với khu vực trồng lúa $(42,5 \mathrm{mg} / \mathrm{L})$ và khu công nghiệp $(39,8 \mathrm{mg} / \mathrm{L})$. Chỉ tiêu TSS của các khu vực nghiên cứu đều đạt mức B1 theo tiêu chuân QCVN 08-MT:2015/BTNMT (Hình 2). Tuy nhiên, chỉ tiêu này khác nhau phụ thuộc vào mục đích sử dụng nước khác nhau ở các khu vực. Chẳng hạn, đối với khu vực trồng lúa, người dân cần có lượng phù sa có trong nước đầu vào để cải tạo đất trong mùa lũ. Bên cạnh đó, quá trình xả thải vào nguồn tiếp nhận từ khâu làm đất, vệ sinh đồng ruộng đã làm chỉ tiêu TSS ở khu vực này cao hơn so với các khu vực khác. TSS là mối quan tâm chính đối với chất lượng nước ở Việt Nam nói chung và Đồng bằng sông Cửu Long nói riêng vì nó dẫn đến chất lượng nước thấp hơn và chi phí xử lý cao hơn [23]. 

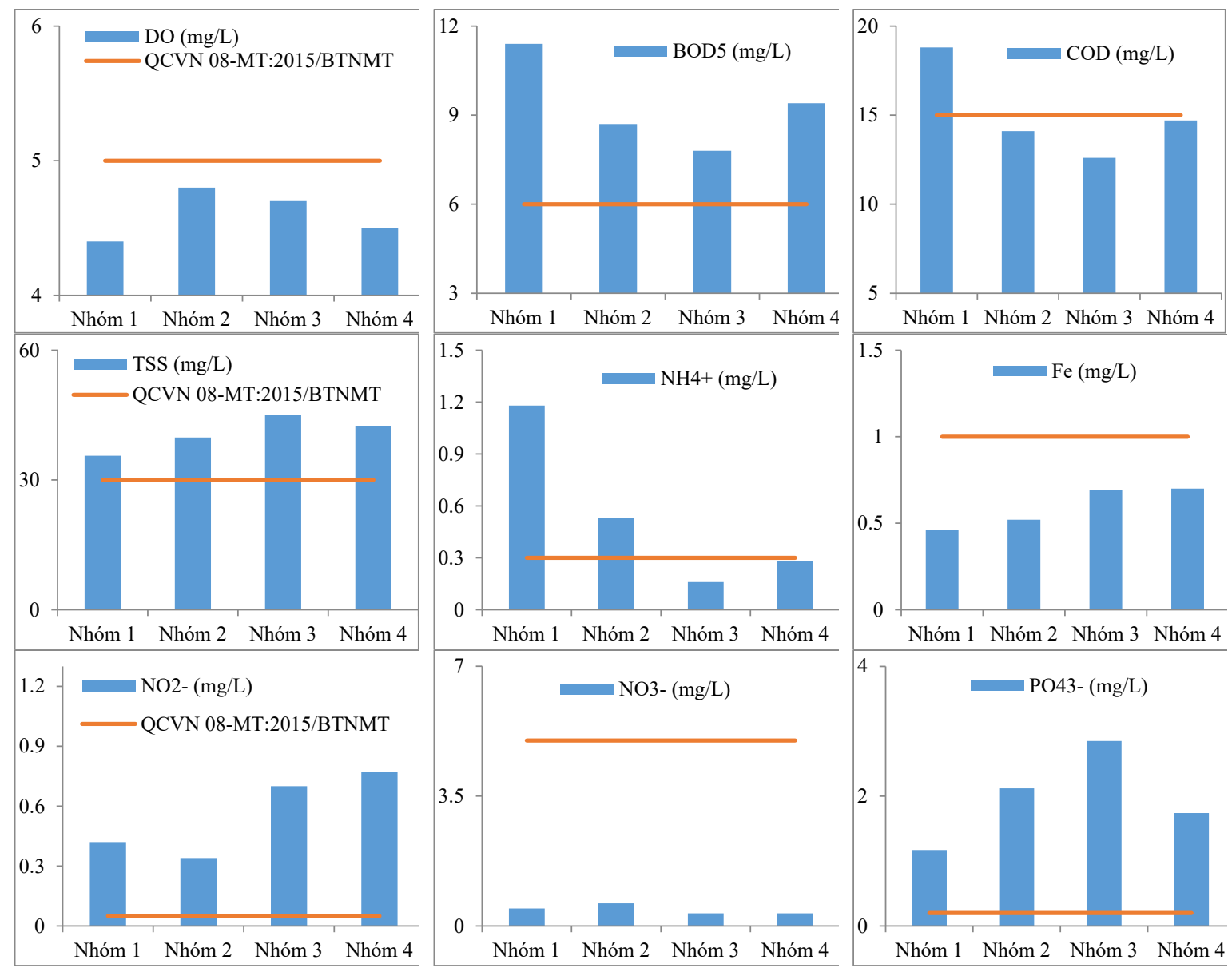

Hình 2. Biểu đồ quan trắc chất lượng nước mặt so với QCVN 08:2015/BTNMT (cột A2).

Hàm lượng amoni $\left(\mathrm{NH}_{4}^{+}\right)$trung bình giữa bốn khu vực là $0,56 \mathrm{mg} / \mathrm{L}$, đạt mức $\mathrm{B} 1$ của QCVN 08-MT:2015/BTNMT (Hình 2). Trong đó, giá trị amoni cao nhất ở khu vực dân cư $(1,18 \mathrm{mg} / \mathrm{L}$, vượt mức $\mathrm{B} 2)$ và khác biệt so với các khu vực còn lại. Hàm lượng $\mathrm{NH}_{4}{ }^{+}$thấp nhất ở khu vực trồng cây ăn trái $(0,16 \mathrm{mg} / \mathrm{L}$, đạt mức $\mathrm{A} 1)$ nhưng khác biệt không ý nghĩa so với khu vực trồng lúa $(0,28 \mathrm{mg} / \mathrm{L}$, đạt mức $\mathrm{A} 1)$. Amoni có mặt trong môi trường nước có nguồn gốc từ các quá trình chuyển hóa khác nhau như nông nghiệp, sinh hoạt và công nghiệp. So với QCVN 08-MT:2015/BTNMT, chỉ tiêu amoni của khu vực trồng cây ăn trái và khu vực trồng lúa đạt mức $\mathrm{A} 1$, trong khi khu công nghiệp đạt mức $\mathrm{B} 1$ và khu dân cư vượt mức B2 1,3 lần (Hình 2).

Hàm lượng sắt $(\mathrm{Fe})$ trong nước dao động từ $0,46-0,7 \mathrm{mg} / \mathrm{L}$ và trung bình là $0,59 \mathrm{mg} / \mathrm{L}$. Hàm lượng sắt cao ở khu vực trồng lúa và trồng cây ăn trái với lần lượt là $0,7 \mathrm{mg} / \mathrm{L}$ và 0,69 $\mathrm{mg} / \mathrm{L}$, cao hơn và khác biệt so với khu công nghiệp và khu dân cư $(0,52$ và $0,46 \mathrm{mg} / \mathrm{L})$. Theo QCVN 08-MT:2015/BTNMT thì hàm lượng sắt khu vực dân cư đạt mức $\mathrm{A} 1$, các khu vực còn lại thuộc mức A2 (Hình 2).

Hàm lượng nitrit $\left(\mathrm{NO}_{2}{ }^{-}\right)$trong nước cũng có sự khác biệt ý nghĩa giữa bốn khu vực nghiên cứu. Trung bình hàm lượng nitrit là $0,55 \mathrm{mg} / \mathrm{L}$ và dao động từ $0,34-, 7 \mathrm{mg} / \mathrm{L}$ (Bảng 1). Tương tự chỉ số sắt, chỉ số nitrit cũng cao ở khu vực trồng lúa và trồng cây ăn trái $(0,77$ $\mathrm{mg} / \mathrm{L}$ và $0,7 \mathrm{mg} / \mathrm{L})$ và thấp ở khu vực dân cư và khu công nghiệp $(0,42 \mathrm{mg} / \mathrm{L}$ và $0,34 \mathrm{mg} / \mathrm{L})$. Chỉ tiêu này theo quy định phải dưới $0,05 \mathrm{mg} / \mathrm{L}$ (QCVN 08-MT:2015/BTNMT), do đó chỉ số này đã vượt khoảng 10-15 lần so với QCVN 08-MT:2015/BTNMT (Hình 2).

Chỉ số nitrat $\left(\mathrm{NO}_{3}{ }^{-}\right)$của cả $4 \mathrm{khu}$ vực nghiên cứu đều nhỏ hơn mức chuẩn $\mathrm{A} 1$ của $\mathrm{QCVN}$ 08-MT:2015/BTNMT (Hình 2). Cụ thể, Bảng 1 cho thấy, chỉ số này trung bình giữa bốn khu vực nghiên cứu là $0,45 \mathrm{mg} / \mathrm{L}$, thấp hơn 4,5 lần so với quy định. Hàm lượng nitrat thấp nhất 
ở khu vực trồng lúa và khu vực trồng cây ăn trái $(0,34 \mathrm{mg} / \mathrm{L})$ và cao nhất ở khu công nghiệp $(0,61 \mathrm{mg} / \mathrm{L})$.

Xét về chỉ tiêu hàm lượng phosphate $\left(\mathrm{PO}_{4}{ }^{3-}\right)$, kết quả Bảng 1 cho thấy có sự khác biệt không ý nghĩa giữa $4 \mathrm{khu}$ vực nghiên cứu. Trung bình hàm lượng $\mathrm{PO}_{4}{ }^{3-}$ là $1,89 \mathrm{mg} / \mathrm{L}$ và dao động từ $1,17 \mathrm{mg} / \mathrm{L}$ (khu dân cư) đến $2,85 \mathrm{mg} / \mathrm{L}$ (khu vực trồng cây ăn trái). Chỉ tiêu này vượt giới hạn mức tối đa B2 (3,8 lần) theo QCVN 08-MT:2015/BTNMT (Hình 2). Nguồn $\mathrm{PO}_{4}{ }^{3-}$ có thể đến từ chất tẩy rửa trong sinh hoạt, phân bón trong nông nghiệp, nước thải công nghiệp sản xuất bột giặt. Khi hàm lượng $\mathrm{PO}_{4}{ }^{3-}$ cao sẽ làm cho rong rêu và tảo trong nước phát triển.

Tóm lại, kết quả nghiên cứu giai đoạn từ năm 2000-2020 về chất lượng nước mặt của TPCT đã cho thấy giá trị $\mathrm{pH}$, nhiệt độ và $\mathrm{PO}_{4}{ }^{3-}$ là không có sự khác biệt giữa các khu vực nghiên cứu trên địa bàn TPCT. Tuy nhiên, các chỉ tiêu $\mathrm{BOD}_{5}, \mathrm{COD}$ và TSS, $\mathrm{NH}_{4}{ }^{+}, \mathrm{Fe}, \mathrm{NO}_{2}{ }^{-}$ và $\mathrm{NO}_{3}{ }^{-}$có sự khác biệt có ý nghĩa giữa các khu vực. Chất lượng nước mặt ở các khu vực đều đạt mức B1 của QCVN 08-MT:2015/BTNMT. Trong đó, đáng lưu ý, riêng chỉ tiêu $\mathrm{NO}_{2}{ }^{-}$và $\mathrm{PO}_{4}{ }^{3-}$ vượt giới hạn cho phép nhiều lần (vượt mức B2) theo QCVN 08-MT:2015/BTNMT (Hình 2). Từ kết quả trên cho thấy nước mặt tại khu vực nghiên cứu đang có dấu hiệu bị ô nhiễm hữu cơ và nguy cơ xuất hiện tình trạng phú dưỡng hóa. Do đó, cần phải có những giải pháp cải thiện chất lượng môi trường sớm [22]. Chất lượng nước mặt ít bị ô nhiễm nhất ở khu vực trồng cây ăn trái và bị ô nhiễm nhiều nhất ở khu vực dân cư.

Bảng 1. Các chỉ tiêu về chất lượng nước mặt tại TPCT theo bốn khu vực.

\begin{tabular}{ccrrrrrrrrrr}
\hline $\begin{array}{c}\text { Khu } \\
\text { vực }\end{array}$ & $\mathbf{p H}$ & $\begin{array}{c}\text { Nhiệt độ } \\
(\mathrm{oC})\end{array}$ & $\begin{array}{c}\text { DO } \\
(\mathrm{mg} / \mathrm{L})\end{array}$ & $\begin{array}{r}\text { BOD5 } \\
(\mathrm{mg} / \mathrm{L})\end{array}$ & $\begin{array}{c}\text { COD } \\
(\mathrm{mg} / \mathrm{L})\end{array}$ & $\begin{array}{c}\text { TSS } \\
(\mathrm{mg} / \mathrm{L})\end{array}$ & $\begin{array}{c}\mathbf{N H}^{+} \\
(\mathrm{mg} / \mathrm{L})\end{array}$ & $\begin{array}{c}\mathbf{F e} \\
(\mathrm{mg} / \mathrm{L})\end{array}$ & $\begin{array}{r}\mathbf{N O}_{2}^{-} \\
(\mathrm{mg} / \mathrm{L})\end{array}$ & $\begin{array}{c}\mathbf{N O}^{-} \\
(\mathrm{mg} / \mathrm{L})\end{array}$ & $\begin{array}{r}\mathbf{P O}^{\mathbf{3}^{-}} \\
(\mathrm{mg} / \mathrm{L})\end{array}$ \\
\hline 1 & 7,07 & 27,2 & $4,4^{\mathrm{c}}$ & $11,4^{\mathrm{a}}$ & $18,8^{\mathrm{a}}$ & $35,6^{\mathrm{b}}$ & $1,18^{\mathrm{a}}$ & $0,46^{\mathrm{b}}$ & $0,42^{\mathrm{b}}$ & $0,47 \mathrm{a}^{\mathrm{b}}$ & 1,17 \\
2 & 7,14 & 27,2 & $4,8^{\mathrm{a}}$ & $8,7 \mathrm{~b}^{\mathrm{c}}$ & $14,1^{\mathrm{b}}$ & $39,8 \mathrm{a}^{\mathrm{b}}$ & $0,53^{\mathrm{b}}$ & $0,52^{\mathrm{b}}$ & $0,34^{\mathrm{b}}$ & $0,61^{\mathrm{a}}$ & 2,12 \\
3 & 7,08 & 27,2 & $4,7^{\mathrm{ab}}$ & $7,8^{\mathrm{c}}$ & $12,6^{\mathrm{b}}$ & $45,1^{\mathrm{a}}$ & $0,16^{\mathrm{c}}$ & $0,69^{\mathrm{a}}$ & $0,70^{\mathrm{a}}$ & $0,34^{\mathrm{b}}$ & 2,85 \\
4 & 7,09 & 27,2 & $4,5^{\mathrm{bc}}$ & $9,4^{\mathrm{b}}$ & $14,7^{\mathrm{b}}$ & $42,5^{\mathrm{a}}$ & $0,28 \mathrm{~b}^{\mathrm{c}}$ & $0,70^{\mathrm{a}}$ & $0,77^{\mathrm{a}}$ & $0,34^{\mathrm{b}}$ & 1,74 \\
$\mathbf{T B}$ & $\mathbf{7 , 0 9}$ & $\mathbf{2 7 , 2}$ & $\mathbf{4 , 6}$ & $\mathbf{9 , 4}$ & $\mathbf{1 5 , 1}$ & $\mathbf{3 9 , 7}$ & $\mathbf{0 , 5 6}$ & $\mathbf{0 , 5 9}$ & $\mathbf{0 , 5 5}$ & $\mathbf{0 , 4 5}$ & $\mathbf{1 , 8 9}$ \\
$\mathrm{F}$ & $0,095^{\mathrm{ns}}$ & $0,994^{\mathrm{ns}}$ & $0,003^{* *}$ & $0,000^{* *}$ & $0,000^{* *}$ & $0,014^{* *}$ & $0,000^{* *}$ & $0,000^{* *}$ & $0,000^{* *}$ & $0,000^{* *}$ & $0,325^{\mathrm{ns}}$ \\
\hline
\end{tabular}

Ghi chú: (1) Khu dân cu; (2) Khu công nghiệp; (3) Khu vục trồng cây ăn trái; (4) Khu vực trồng lúa. ns: khác biệt không ý nghĩa thống kê ở mức 5\%; *: Khác biệt thống kê ở mức ý nghĩa 5\%; **: Khác biệt thống kê ở múc ý nghĩa 1\%. Trong cùng một cột các chũ theo sau các số giống nhau thì khác biệt không ý nghĩa về mặt thống kê.

\subsubsection{Kết quả chất lượng nước mặt theo thời gian lấy mẫu trong năm}

Diễn biến của chất lượng nước mặt theo thời gian lấy mẫu trong năm được thể hiện ở Bảng 2. Kết quả cho thấy, chỉ tiêu về $\mathrm{pH}$, nhiệt độ, sắt $(\mathrm{Fe})$, nitrit $\left(\mathrm{NO}_{2}{ }^{-}\right)$và $\mathrm{PO}_{4}{ }^{3-}$ có sự khác biệt ý nghĩa thống kê trong 4 đợt lấy mẫu trong năm. Trong khi các chỉ tiêu $\mathrm{DO}, \mathrm{BOD}_{5}, \mathrm{COD}$, TSS, $\mathrm{NH}_{4}{ }^{+}$và $\mathrm{NO}_{3}{ }^{-}$lại không có sự khác biệt thống kê ở mức $5 \%$. Giá trị pH trung bình cả năm là 7,1 và đa phần các tháng trong năm đều có $\mathrm{pH}$ bằng 7,1 , ngoại trừ đợt lấy mẫu tháng 3 có giá trị $\mathrm{pH}$ là 7,2 . Nhìn chung, sự biến động giá trị về $\mathrm{pH}$ là không đáng kể giữa các đợt lấy mẫu nước trong năm ở tất cả 20 địa điểm nghiên cứu. Trung bình nhiệt độ nước là $27,2^{\circ} \mathrm{C}$ và dao động từ $26,8^{\circ} \mathrm{C}$ (tháng 6 ) đến $27,4^{\circ} \mathrm{C}$ (tháng 3 và 12 ). Sự chênh lệch về nhiệt độ nước giữa các đợt lấy mẫu trong năm chỉ dao động tối đa $0,6^{\circ} \mathrm{C}$. Hàm lượng $\mathrm{DO}$ khác biệt không ý nghĩa giữa các đợt (tháng) lấy mẫu trong năm, trung bình là $4,6 \mathrm{mg} / \mathrm{L}$ và dao động từ $4,5-$ $4,7 \mathrm{mg} / \mathrm{L}$. Hàm lượng $\mathrm{BOD}_{5}$ và $\mathrm{COD}$ có khuynh hướng như nhau đối với 4 đợt lấy mẫu trong năm. Tuy sự khác biệt không có ý nghĩa về mặt thống kê, nhưng hai chỉ tiêu này có khuynh hướng cao ở tháng 12 và thấp ở tháng 9 (Bảng 2). Đối với chỉ số TSS cũng có sự khác biệt không ý nghĩa ở mức $5 \%$, hàm lượng TSS có khuynh hướng thấp ở tháng $6(35,6 \mathrm{mg} / \mathrm{L})$ và cao nhất ở tháng $9(42,2 \mathrm{mg} / \mathrm{L})$. Tóm lại, chỉ tiêu hóa lý của nước ở 4 thời điểm lấy mẫu trong năm khác biệt không nhiều và có xu hướng xấu hơn ở tháng 12. 
Kết quả này cho thấy hàm lượng amoni và nitrat ổn định trong năm, trong đó hàm lượng amoni đạt cột $\mathrm{B} 1$ của QCVN 08-MT:2015/BTNMT, hàm lượng nitrat rất thấp và nhỏ hơn quy định trong cột A1.

Hàm lượng sắt thấp nhất ở đợt lấy mẫu nước vào tháng 3 với $0,422 \mathrm{mg} / \mathrm{L}$ và cao nhất vào tháng $9(0,667 \mathrm{mg} / \mathrm{L})$, nhưng khác biệt không ý nghĩa với hàm lượng sắt trong đợt lấy mẫu tháng $6(0,646 \mathrm{mg} / \mathrm{L})$ và tháng $12(0,618 \mathrm{mg} / \mathrm{L})$ về mặt thống kê. Nhìn chung, hàm lượng sắt dao động từ $0,422-0,667 \mathrm{mg} / \mathrm{L}$ và trung bình là $0,587 \mathrm{mg} / \mathrm{L}$ (Bảng 2$)$. Dựa theo quy chuẩn quốc gia năm 2015 , hàm lượng sắt trong tháng 3 đạt cột $\mathrm{A} 1$, tuy nhiên các tháng tiếp theo thì hàm lượng sắt nằm trong nhóm $\mathrm{A} 2$ của quy chuẩn này.

Trung bình hàm lượng nitrit trong năm của các khu vực nghiên cứu là $0,547 \mathrm{mg} / \mathrm{L}$, dao động từ $0,377-0,701 \mathrm{mg} / \mathrm{L}$ (Bảng 2 ). Hàm lượng nitrit cao nhất ở đợt lấy mẫu nước tháng 6 $(0,701 \mathrm{mg} / \mathrm{L})$, khác biệt không ý nghĩa với hàm lượng nitrit ở tháng $9(0,61 \mathrm{mg} / \mathrm{L})$, nhưng khác biệt ý nghĩa so với các đợt lấy mẫu nước còn lại trong năm. Hàm lượng nitrit thấp nhất ở đợt lấy mâ̂u nước tháng $3(0,377 \mathrm{mg} / \mathrm{L})$. Nhìn vào hàm lượng nitrit cho thấy, tất cả đều vượt quy chuẩn cho phép, nhưng khuynh hướng hàm lượng nitrit cao nhất ở tháng 6 trong năm và sau đó giảm dần theo thời gian lấy mẫu tiếp theo.

Hàm lượng $\mathrm{PO}_{4}{ }^{3-}$ trung bình trong năm là $1,849 \mathrm{mg} / \mathrm{L}$ và dao động từ $0,297-3,105 \mathrm{mg} / \mathrm{L}$. Hàm lượng $\mathrm{PO}_{4}{ }^{3-}$ thấp nhất vào tháng $6(0,297 \mathrm{mg} / \mathrm{L})$ nhưng khác biệt không ý nghĩa so với tháng $9(0,461 \mathrm{mg} / \mathrm{L})$. Hàm lượng $\mathrm{PO}_{4}{ }^{3-}$ cao nhất vào tháng $3(3,105 \mathrm{mg} / \mathrm{L})$ nhưng khác biệt không ý nghĩa so với tháng $12(2,948 \mathrm{mg} / \mathrm{L})$. Hàm lượng $\mathrm{PO}_{4}{ }^{3-}$ có khuynh hướng tăng theo thời gian lấy mẫu nước trong năm tương tự với chỉ tiêu nitrit, nhưng khác thời điểm cao nhất và thấp nhất. Thời điểm hàm lượng $\mathrm{PO}_{4}{ }^{3-}$ thấp nhất vào tháng 6 và sau đó tăng dần đến cao nhất vào tháng 3 năm sau. Trong khi đó hàm lượng nitrit cao nhất vào tháng 6 và giảm dần đến thấp nhất vào tháng 3 năm sau. Kết quả nghiên cứu này cho thấy chất lượng nước mặt có khuynh hướng bị ô nhiễm nhiều hơn ở giai đoạn cuối năm thể hiện qua hai giá trị của chỉ số $\mathrm{BOD}_{5}$ và $\mathrm{COD}$ cao do thời điểm đó nguồn nước trên các hệ thống kênh mương bắt đầu cạn.

Bảng 2. Chỉ tiêu chất lượng nước mặt theo 04 đợt lấy mẫu trong năm.

\begin{tabular}{|c|c|c|c|c|c|c|c|c|c|c|c|}
\hline Tháng & pH & $\begin{array}{c}\text { Nhiệt độ } \\
\left({ }^{\circ} \mathrm{C}\right)\end{array}$ & $\begin{array}{c}\text { DO } \\
(\mathrm{mg} / \mathrm{L})\end{array}$ & $\begin{array}{c}\mathbf{B O D}_{5} \\
(\mathrm{mg} / \mathrm{L})\end{array}$ & $\begin{array}{c}\text { COD } \\
(\mathrm{mg} / \mathrm{L}) \\
\end{array}$ & $\begin{array}{c}\text { TSS } \\
(\mathrm{mg} / \mathrm{L}) \\
\end{array}$ & $\begin{array}{c}\mathbf{N H}_{4}{ }^{+} \\
(\mathrm{mg} / \mathrm{L}) \\
\end{array}$ & $\begin{array}{c}\mathbf{F e} \\
(\mathrm{mg} / \mathrm{L})\end{array}$ & $\begin{array}{c}\mathbf{N O}_{2}^{-} \\
(\mathrm{mg} / \mathrm{L}) \\
\end{array}$ & $\begin{array}{c}\mathbf{N O}_{3}^{-} \\
(\mathrm{mg} / \mathrm{L}) \\
\end{array}$ & $\begin{array}{c}\mathbf{P O}_{4}{ }^{\mathbf{3}^{-}} \\
(\mathrm{mg} / \mathrm{L})\end{array}$ \\
\hline 3 & $7,2^{\mathrm{a}}$ & $27,4^{a}$ & 4,7 & 9,3 & 14,8 & 42,0 & 0,709 & $0,422^{b}$ & $0,377^{\mathrm{c}}$ & 0,433 & $3,105^{\mathrm{a}}$ \\
\hline 6 & $7,1^{\mathrm{b}}$ & $26,8^{b}$ & 4,6 & 9,5 & 15,3 & 35,6 & 0,576 & $0,646^{\mathrm{a}}$ & $0,701^{\mathrm{a}}$ & 0,473 & $0,297^{b}$ \\
\hline 9 & $7,1^{\mathrm{b}}$ & $27,2^{\mathrm{a}}$ & 4,6 & 8,5 & 14,2 & 42,2 & 0,425 & $0,667^{\mathrm{a}}$ & $0,610^{\mathrm{ab}}$ & 0,466 & $0,461^{\mathrm{b}}$ \\
\hline 12 & $7,1^{\mathrm{b}}$ & $27,4^{\mathrm{a}}$ & 4,5 & 10,2 & 16,2 & 38,9 & 0,509 & $0,618^{a}$ & $0,507^{\mathrm{bc}}$ & 0,415 & $2,948^{\mathrm{a}}$ \\
\hline TB & 7,1 & 27,2 & 4,6 & 9,4 & 15,1 & 39,7 & $\mathbf{0 , 5 5 7}$ & $\mathbf{0 , 5 8 7}$ & $\mathbf{0 , 5 4 7}$ & 0,446 & 1,849 \\
\hline $\mathrm{F}$ & $0,006^{* *}$ & $0,001 * *$ & $0,767^{\mathrm{ns}}$ & $0,121^{\mathrm{ns}}$ & $0,300^{\mathrm{ns}}$ & $0,100^{\mathrm{ns}}$ & $0,398^{\text {ns }}$ & $0,000 * *$ & $0,000 * *$ & $0,844^{\mathrm{ns}}$ & $0001 * *$ \\
\hline
\end{tabular}

Ghi chú: ns: khác biệt không ý nghĩa thống kê ở mức 5\%; *: Khác biệt thống kê ở mức ý nghĩa 5\%; **: Khác biệt thống kê ở mức ý nghĩa 1\%. Trong cùng một cột các chũ theo sau các số giống nhau thì khác biệt không ý nghĩa về mặt thống kê.

\subsubsection{Phân tích mối tương quan giữa các chỉ tiêu chất lượng nước tại TPCT}

Nhằm xác định được xu hướng chất lượng nước theo thời gian, đồng thời tìm sự tương quan giữa các yếu tố chất lượng nước, hệ số tương quan Pearson được sử dụng để phân tích sự tương quan này. Kết quả phân tích mối tương quan giữa các chỉ tiêu chất lượng nước trong vùng nghiên cứu cho thấy, theo thời gian (năm) trong giai đoạn 20 năm từ năm 2000 đến năm 2020 nồng độ các chỉ tiêu chất lượng nước có xu hướng giảm (tương quan âm) bao gồm: nhiệt độ, $\mathrm{DO}, \mathrm{BOD}_{5}, \mathrm{COD}, \mathrm{NH}_{4}{ }^{+}, \mathrm{Fe}, \mathrm{NO}_{2}{ }^{-}$và $\mathrm{PO}_{4}{ }^{3-}$. Trong khi đó, $\mathrm{pH}, \mathrm{DO}, \mathrm{TSS}_{\text {và }} \mathrm{NO}_{3}{ }^{-}$ có xu hướng tăng (tương quan dương) theo thời gian trong giai đoạn 20 năm nghiên cứu (Bảng 3).

Kết quả khảo sát trong thời gian 20 năm cho thấy chỉ có giá trị $\mathrm{pH}$ có tương quan âm với các đợt lâyy mẫu trong năm $(\mathrm{r}=-0,11)$, nghĩa là giá trị $\mathrm{pH}$ có khuynh hướng cao ở đợt lấy 
mẫu trong tháng 3 và giảm dần đến đợt lấy mẫu trong tháng 12. Đối với hàm lượng sắt thì có khuynh hướng ngược lại, hàm lượng sắt có khuynh hướng thấp ở tháng 3 và tăng dần ở tháng 12 vì chúng có mối tương quan dương $(\mathrm{r}=0,145)$. Kết quả này cũng phù hợp với kết quả phân tích ở Bảng 2.

Chỉ tiêu $\mathrm{pH}$ tương quan âm với các chỉ tiêu chất lượng nước trong thời gian 20 năm gồm: nhiệt độ, $\mathrm{BOD}_{5}, \mathrm{NH}_{4}{ }^{+}, \mathrm{Fe}, \mathrm{NO}_{2}{ }^{-}$và $\mathrm{PO}_{4}{ }^{3-}$. Giá trị $\mathrm{pH}$ trong nghiên cứu này chỉ tương quan dương với hai chỉ tiêu là $\mathrm{DO}(\mathrm{r}=0,22)$ và $\mathrm{NO}_{3}{ }^{-}(\mathrm{r}=0,15)$. Trong khi đó, nhiệt độ có sự tương quan dương với các chỉ tiêu như $\mathrm{BOD}_{5}, \mathrm{COD}, \mathrm{NH}_{4}{ }^{+}, \mathrm{Fe}$ và $\mathrm{PO}_{4}{ }^{3-}$ và tương quan âm với các chỉ tiêu như $\mathrm{pH}$, TSS và $\mathrm{NO}_{3}^{-}$.

Hàm lượng oxy hòa tan $(\mathrm{DO})$ tương quan âm với rất nhiều chỉ tiêu chất lượng nước như: $\mathrm{BOD}_{5}, \mathrm{COD}, \mathrm{TSS}, \mathrm{NH}_{4}{ }^{+}, \mathrm{Fe}, \mathrm{NO}_{2}{ }^{-}$, nghĩa là khi 6 chỉ tiêu này tăng thì hàm lượng oxy hòa tan trong nước sẽ bị giảm. Kết quả này đúng với tính chất của nước vì khi các chỉ tiêu trên tăng, cần phải có lượng oxy để phân hủy các chất này và làm cho hàm lượng oxy bị giảm.

Hàm lượng $\mathrm{BOD}_{5}$ có mối tương quan rất chặt với hàm lượng $\mathrm{COD}$ trong nghiên cứu này $(\mathrm{r}=0,934)$, chứng tỏ trong nghiên cứu này chúng ta có thể sử dụng một chỉ tiêu $\mathrm{BOD}_{5}$ hoặc $\mathrm{COD}$ để đánh giá chung cho chất lượng nước. Xét về tổng thể, hàm lượng $\mathrm{BOD}_{5}$ có mối tương quan dương với các chỉ tiêu $\mathrm{COD}, \mathrm{NH}_{4}{ }^{+}, \mathrm{Fe}, \mathrm{NO}_{2}{ }^{-}, \mathrm{PO}_{4}{ }^{3-}$ và nhiệt độ. Hàm lượng $\mathrm{BOD}_{5}$ chỉ tương quan âm với giá trị $\mathrm{pH}$ và hàm lượng $\mathrm{NO}_{3}{ }^{-}$. Bên cạnh đó, hàm lượng $\mathrm{COD}$ có sự tương quan đến tất cả các chỉ tiêu phân tích nước, ngoại trừ giá trị $\mathrm{pH}$ và hàm lượng $\mathrm{PO}_{4}{ }^{3-}$. Hàm lượng $\mathrm{COD}$ có sự tương quan dương đến các chỉ tiêu: nhiệt độ, $\mathrm{BOD}_{5}, \mathrm{TSS}$, $\mathrm{NH}_{4}{ }^{+}, \mathrm{Fe}$ và $\mathrm{NO}_{2}^{-}$, tương quan âm với $\mathrm{DO}$ và $\mathrm{NO}_{3}^{-}$(Bảng 3 ).

Tổng chất rắn lơ lửng trong nước (TSS) có ít mối tương quan với các chỉ tiêu chất lượng nước trong nghiên cứu này. Kết quả Bảng 3 cho thấy hàm lượng TSS có mối tương quan âm với hàm lượng $\mathrm{PO}_{4}{ }^{3-}$ và nhiệt độ. Bên cạnh đó $\mathrm{TSS}$ có tương quan dương với hàm lượng COD trong nước. Xét về các chỉ tiêu hóa học Bảng 3 cho thấy hàm lượng $\mathrm{NH}_{4}{ }^{+}$có mối tương quan tương đối chặt với chỉ tiêu $\mathrm{BOD}_{5}(\mathrm{r}=0,488)$ và $\mathrm{COD}(\mathrm{r}=0,492)$. Hàm lượng sắt có mối tương quan đến hầu hết các chỉ tiêu phân tích nhưng tương quan chặt nhất với chỉ tiêu $\mathrm{NO}_{2}{ }^{-}(\mathrm{r}=0,519)$ và $\mathrm{DO}(\mathrm{r}=-0,421)$. Đối với chỉ tiêu $\mathrm{NO}_{2}^{-}$, kết quả phân tích cho thấy có sự tương quan đến hầu hết các chỉ tiêu. Ngoài sự tương quan chặt với hàm lượng sắt, chỉ tiêu $\mathrm{NO}_{2}{ }^{-}$còn có sự tương quan chặt với các chỉ tiêu: $\mathrm{DO}(\mathrm{r}=-0,433)$ và $\mathrm{BOD}_{5}(\mathrm{r}=0,366)$. Hàm lượng $\mathrm{NO}_{3}{ }^{-}$có mối tương quan dương chặt với chỉ tiêu $\mathrm{DO}(\mathrm{r}=0,31)$. Trong khi đó, chỉ số $\mathrm{PO}_{4}{ }^{3-}$ có mối tương quan dương đối với 4 chỉ tiêu sau: nhiệt độ, $\mathrm{BOD}_{5}, \mathrm{NH}_{4}{ }^{+}$và $\mathrm{Fe}$. Sự tương quan giữa $\mathrm{PO}_{4}{ }^{3-}$ và $\mathrm{NH}_{4}{ }^{+}$là cao nhất $(\mathrm{r}=0,725)$, kế đến là với nhiệt độ $(\mathrm{r}=0,487)$.

Bảng 3. Kết quả phân tích tương quan giữa các yếu tố chất lượng nước thông qua hệ số tương quan Pearson.

\begin{tabular}{|c|c|c|c|c|c|c|c|c|c|c|c|}
\hline Chỉ tiêu & Năm & Tháng & pH & $\begin{array}{c}\text { Nhiệt } \\
\text { độ }\end{array}$ & DO & BOD $_{5}$ & COD & TSS & $\mathrm{NH}_{4}^{+}$ & $\mathrm{Fe}$ & $\mathrm{NO}_{2}^{-}$ \\
\hline Tháng & -.011 & 1 & & & & & & & & & \\
\hline pH & $.277^{* *}$ & $-.110^{* *}$ & 1 & & & & & & & & \\
\hline Nhiệt độ & $-.149^{* *}$ & .031 & $-.129^{*}$ & 1 & & & & & & & \\
\hline DO & $.525^{* *}$ & -.032 & $.220^{* *}$ & -.053 & 1 & & & & & & \\
\hline BOD5 & $-.073^{*}$ & .027 & $-.102^{* *}$ & $.353^{* *}$ & $-.463^{* *}$ & 1 & & & & & \\
\hline COD & -.024 & .034 & -.041 & $.208^{* *}$ & $-.420^{* *}$ & $.934^{* *}$ & 1 & & & & \\
\hline TSS & $.216^{* *}$ & -.021 & .087 & $-.174^{* *}$ & $-.111^{*}$ & .068 & $.197^{* *}$ & 1 & & & \\
\hline $\mathrm{NH}_{4}{ }^{+}$ & $-.132^{* *}$ & -.051 & $-.072^{*}$ & $.184^{* *}$ & $-.287^{* *}$ & $.488^{* *}$ & $.492^{* *}$ & -.087 & 1 & & \\
\hline $\mathrm{Fe}$ & $-.612^{* *}$ & $.145^{* *}$ & $-.130^{* *}$ & $.200^{* *}$ & $-.421^{* *}$ & $.166^{* *}$ & $.125^{* *}$ & -.009 & $.159^{* *}$ & 1 & \\
\hline $\mathrm{NO}_{2}^{-}$ & $-.554^{* *}$ & .047 & $-.244^{* *}$ & -.010 & $-.433^{* *}$ & $.366^{* *}$ & $.289^{* *}$ & -.079 & $.121^{* *}$ & $.519^{* *}$ & 1 \\
\hline $\mathrm{NO}_{3}^{-}$ & $.461^{* *}$ & -.010 & $.150^{* *}$ & $-.143^{* *}$ & $.310^{* *}$ & $-.120^{* *}$ & $-.104^{* *}$ & -.062 & -.061 & $-.260^{* *}$ & $-.249^{* *}$ \\
\hline $\mathrm{PO}_{4}{ }^{3-}$ & $-.399^{* *}$ & -.002 & -.095 & $.487^{* *}$ & -.080 & $.279^{* *}$ & .055 & $-.143^{* *}$ & $.725^{* *}$ & $.295^{* *}$ & .048 \\
\hline
\end{tabular}

**: các yếu tố có sự tưởng quan ở mức ý nghĩa $1 \%$; *: các yếu tố có sự tưởng quan ở mức ý nghã $5 \%$; Khác: không có sự tương quan ở mức ý nghĩa 5\%. 


\subsection{Kết quả khảo sát tình hình chất lượng nguồn nuớc của ngườ dân khu vục TPCT}

\subsubsection{Tình hình sử dụng nước cho các hoạt động của người dân địa bàn TPCT}

a) Tình hình sử dụng nước cho các hoạt động theo từng khu vực

Người dân có thể sử dụng đa dạng các nguồn nước như nước máy, nước sông, nước mưa, nước ngầm và các nguồn nước đã được chế biến khác để phục vụ cho các mục đích hoạt động của mình tùy theo điều kiện thực tế. Kết quả nghiên cứu cho thấy $100 \%$ nông dân trồng lúa và trồng cây ăn trái sử dụng trực tiếp nguồn nước sông không qua xử lý để cung cấp nước cho ruộng sản xuất của mình (Hình 3). Hai hoạt động nông nghiệp này chỉ sử dụng nước mặt mà không cần tới nguồn nước ngầm do Cần Thơ nằm ven sông Hậu và có đủ nguồn nước ngọt để cung cấp cho nông nghiệp, không cần khai thác nguồn nước ngầm để sản xuất. Tuy nhiên, đối với nguồn nước sinh hoạt, kết quả nghiên cứu cho thấy có sự đa dạng về việc lựa chọn nguồn nước sử dụng. Phần lớn người dân ở TPCT hiện nay sử dụng nước máy cho sinh hoạt (chiếm 77,2\% trong tổng số 145 hộ khảo sát). Trong khi đó, vấn còn 20,7\% nông dân sử dụng trực tiếp nguồn nước từ sông cho hoạt động sinh hoạt của mình. Ngoài ra, có $2,1 \%$ số hộ được khảo sát sử dụng nguồn nước khác cho sinh hoạt, tuy nhiên các đáp viên không liệt kê cụ thể nguồn nước khác là nguồn nước nào. Do khảo sát các cá nhân nên nghiên cứu không tập trung vào nguồn nước sử dụng cho các công ty, xí nghiệp tại khu công nghiệp.

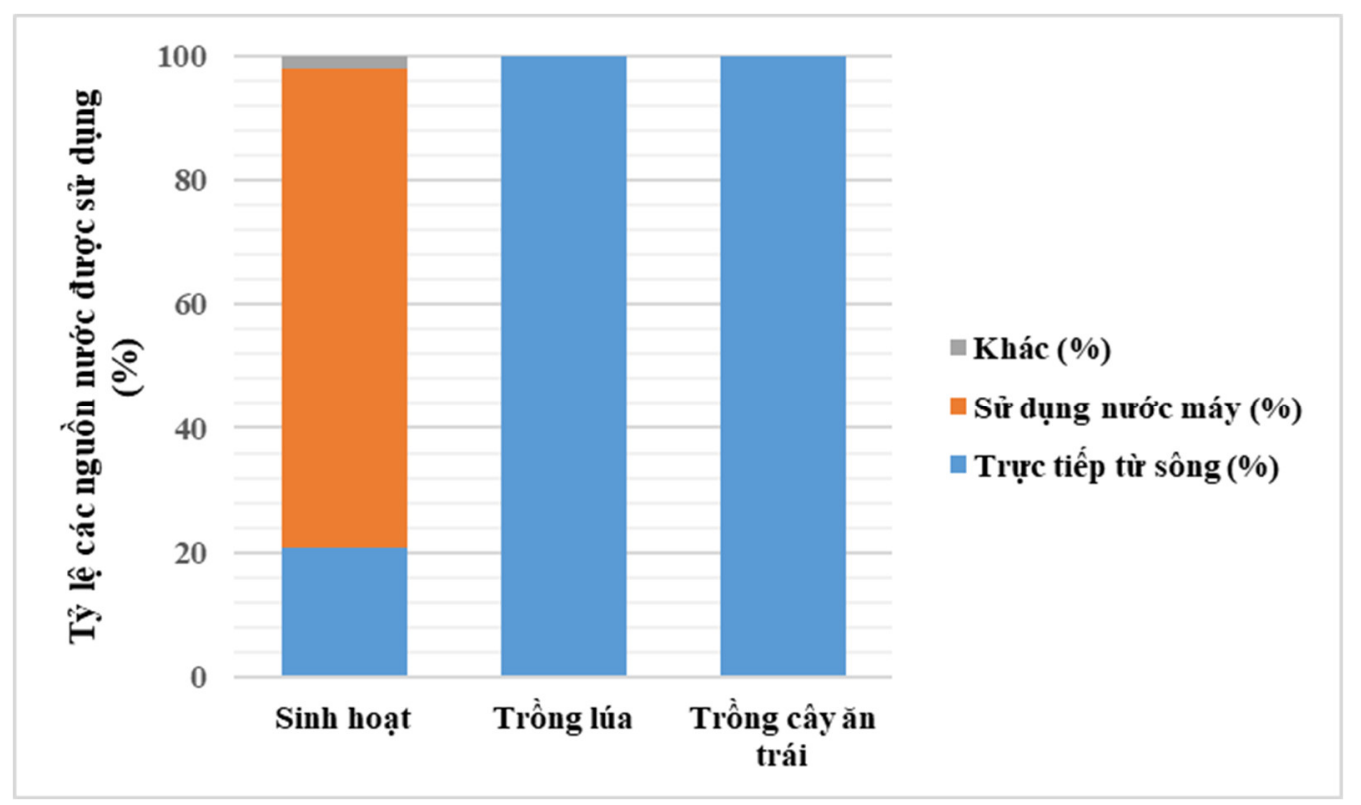

Hình 3. Tỷ lệ xử lý nước thải phát sinh từ các hoạt động của người dân trên địa bàn TPCT.

b) Tình hình xử lý nước thải đối với các hoạt động của người dân trên địa bàn TPCT

Việc quản lý nguồn nước thải của các cá nhân, doanh nghiệp phụ thuộc rất lớn vào ý thức, cơ sở hạ tầng, điều kiện kinh tế của họ. Đối với nghiên cứu này, mục tiêu xác định xem nguồn nước sau khi được người dân sử dụng có được xử lý trước khi thải ra ngoài hay không. Kết quả nghiên cứu cho thấy, đa phần người dân thải trực tiếp nguồn nước thải ra sông cho tất cả các hoạt động của mình. Trong đó, cao nhất đối với các người dân trồng lúa và trồng cây ăn trái với tỷ lệ các hộ thải nguồn nước thải trực tiếp ra sông lần lược là $97,4 \%$ và $97,3 \%$. Trong khi đó, đối với nguồn nước thải sinh hoạt cũng đã có 75,5\% số hộ thải trực tiếp ra sông, không thông qua xử lý trước. Đối với việc xử lý nguồn nước thải trước khi đưa ra sông chiếm một tỷ lệ rất thấp. Cụ thể có $24,3 \%$ người dân xử lý nước thải sinh hoạt trước khi thải ra sông, đối với trồng lúa và trồng cây ăn trái hầu như không có xử lý, chỉ có khoảng 2,6$2,7 \%$ nguồn nước thải từ hai hoạt động sản xuất này được xử lý bằng các hệ thống ao lắng trước khi hòa vào nguồn tiếp nhận (Hình 4). Tương tự như nguồn nước sử dụng, nguồn nước thải tại các công ty, xí nghiệp không đề cập trong nghiên cứu này. 


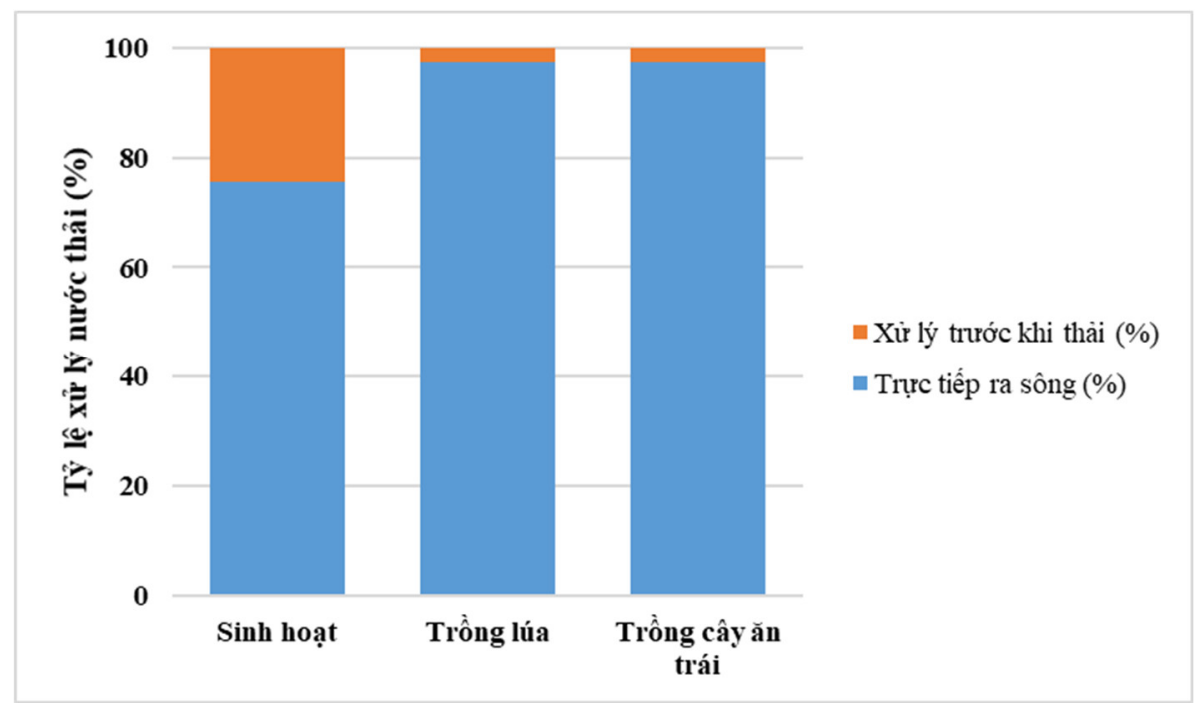

Hình 4. Hiện trạng xử lý nước thải đối với các hoạt động của người dân địa bàn TPCT.

\subsection{2. Đánh giá nhận thức của người dân về môi trường nước}

a) Quan điểm của người dân về các hoạt động trồng trọt, sinh hoạt và chế biến đối với chất lượng nguồn nước mặt

Nhằm tìm hiểu các quan điểm của người dân đối với việc ảnh hưởng của nguồn nước mặt thông qua các hoạt động của mình trên địa bàn TPCT. Nghiên cứu đã tiến hành khảo sát ý kiến 145 hộ. Kết quả khảo sát cho thấy đa phần người dân cho rằng các hoạt động sản xuất của các khu công nghiệp là yếu tố chính làm cho môi trường nước mặt trên địa bàn TPCT bị ảnh hưởng, với 131 người đã trả lời (chiếm 90,3\% số hộ được khảo sát). Tiếp theo lần lượt là hoạt động trồng lúa $(71,0 \%)$, hoạt động trồng cây ăn trái $(66,7 \%)$ và thấp nhất ở các hoạt động sinh hoạt của con người $(53,8 \%)$. Nhìn chung, tất cả đều cho rằng các hoạt động này của con người đã làm ảnh hưởng đến chất lượng nguồn nước mặt $(>50 \%)$, cụ thể dao động từ $53,8 \%-90,3 \%$ cho tất cả các hoạt động (Bảng 4 ).

Bảng 4. Nhận xét của người dân về các hoạt động của con người làm ảnh hưởng môi trường nước mặt.

\begin{tabular}{rlcc}
\hline STT & Biến & Số người & Tỷ lệ (\%) \\
\hline 1 & Trồng lúa ảnh hưởng đến môi trường & 103 & 71,0 \\
2 & Trồng cây ăn trái ảnh hưởng đến môi trường & 96 & 66,7 \\
3 & Khu công nghiệp ảnh hưởng đến môi trường & 131 & 90,3 \\
4 & Các hoạt động sinh hoạt ảnh hưởng đến môi trường & 78 & 53,8 \\
\hline
\end{tabular}

b) Các lý do làm ô nhiễm môi trường nước mặt

Đối với sản xuất lúa, người dân cho rằng có 4 lý do chủ yếu dẫn đến ô nhiễm nguồn nước mặt trong quá trình sản xuất như việc nông dân sử dụng quá nhiều thuốc bảo vệ thực vật (BVTV) với 44,8\% trong tổng số 145 hộ được khảo sát, kế đến là việc bón nhiều phân hóa học cũng làm ảnh hưởng đến chất lượng nguồn nước mặt $(26,2 \%)$. Ngoài ra, còn hai yếu tố có thể gây ảnh hưởng xấu đến môi trường nước mặt trong địa bàn TPCT là quá trình xả thải trong trồng lúa $(13,8 \%$ ) và vứt bừa bãi các vật dụng nông nghiệp như vỏ chai thuốc, rơm rạ với $6,9 \%$ ý kiến (Hình 5 ).

Đối với trồng cây ăn trái, kết quả khảo sát Hình 5 cho thấy có 4 yếu tố đã ảnh hưởng đến chất lượng nước mặt tương tự như trồng lúa. Người dân cũng cho rằng mức độ ảnh hưởng của trồng cây ăn trái đến môi trường nước mặt cao nhất do sử dụng thuốc BVTV $(42,8 \%)$ và thấp nhất ở vứt bừa bãi các hoạt động sản xuất $(7,6 \%)$. Tuy nhiên, có sự khác biệt về việc nhận xét yếu tố phân bón và xả thải ra sông đối với hai hoạt động sản xuất này. Đối với trồng 
cây ăn trái thì hoạt động xả thải được cho là có ảnh hưởng nhiều hơn so với việc sử dụng phân bón. Cụ thể có $26,2 \%$ người trả lời cho rằng xả thải làm ảnh hưởng đến nguồn nước mặt. Trong khi đó, 20,7\% người được khảo sát cho rằng việc bón phân làm ảnh hưởng đến chất lượng nước mặt (Hình 5). Kết quả nghiên cứu này cho thấy, việc sử dụng phân bón làm ô nhiễm môi trường nước ở loại hình sản xuất lúa cao hơn đối với trồng cây ăn trái.

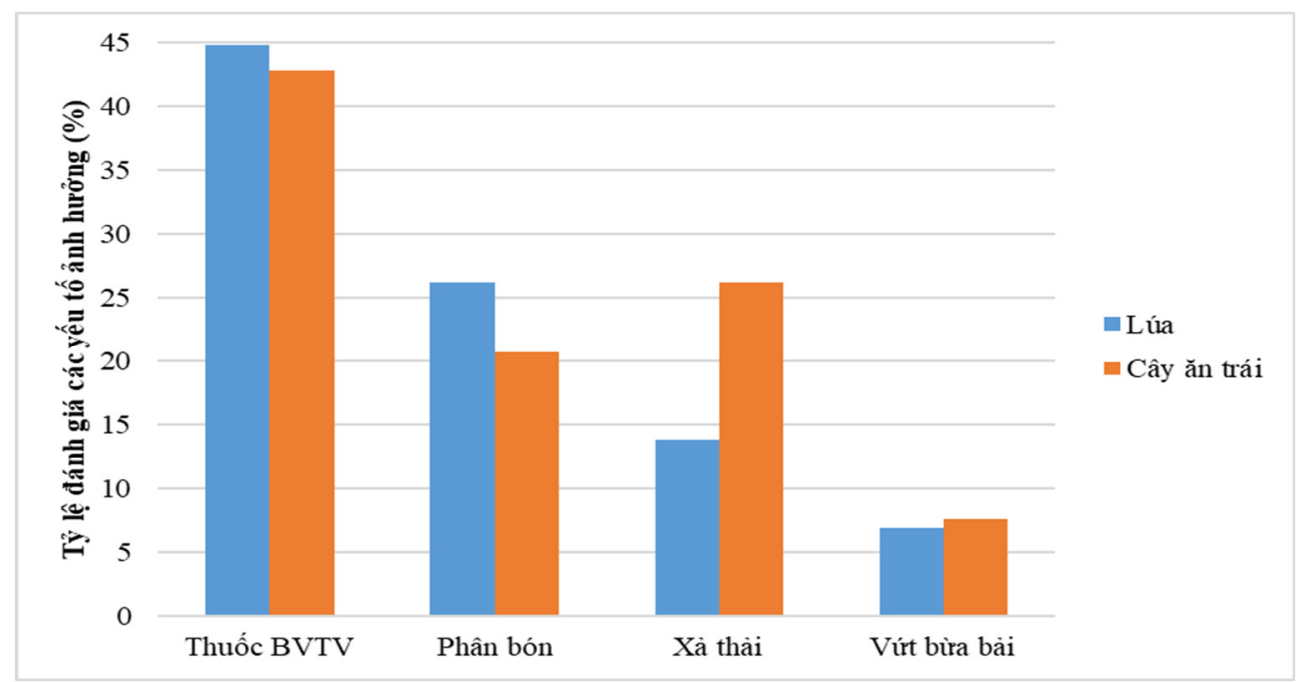

Hình 5. Quan điểm của người dân về các yếu tố ảnh hưởng đến nguồn nước do sản xuất lúa và trồng cây ăn trái.

Qua quá trình khảo sát người dân về các yếu tố ảnh hưởng đến chất lượng nước mặt tại TPCT do hoạt động ở khu công nghiệp gây ra Hình 6 cho thấy, đối với khu công nghiệp có 04 yếu tố chính làm ảnh hưởng gồm: (1) nước thải trực tiếp từ các khu công nghiệp ra sông chiếm tỷ lệ cao nhất (chiếm $55,2 \%$ ); (2) khói bụi do quá trình sản xuất ở khu công nghiệp gây ra (chiếm 52,4\%); (3) do các chất thải rắn gây ra (chiếm 32,4\%) và (4) do chất thải hóa học gây ra (chiếm 13,1\%).

Đối với các ảnh hưởng của khu dân cư, kết quả khảo sát Hình 6 cho thấy chỉ có hai yếu tố làm ảnh hưởng đến chất lượng nguồn nước mặt là do khói bụi từ các phương tiện giao thông (chiếm $11,7 \%$ ) và do rác thải sinh hoạt gây ra (chiếm 9,3\%).

Nhìn chung, đối với các yếu tố ảnh hưởng do khu công nghiệp và khu dân cư đối với chất lượng môi trường nước mặt tại TPCT được xác định do chất thải trong hoạt động sản xuất và sinh hoạt hàng ngày.

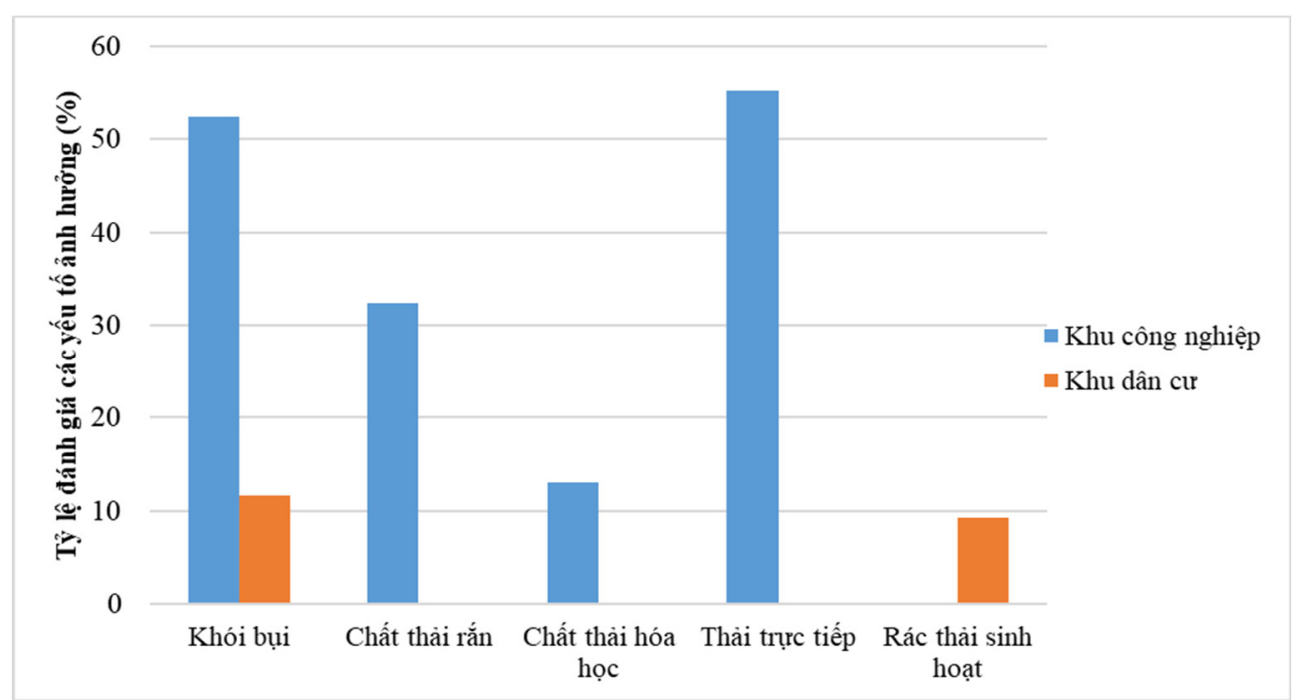

Hình 6. Các yếu tố ảnh hưởng đến nguồn nước mặt từ hoạt động của các khu công nghiệp và khu dân cư. 
c) Giải pháp hạn chế ô nhiễm môi trường nước mặt

Nhằm hạn chế ô nhiễm nguồn nước trong quá trình sản xuất nông nghiệp, các hoạt động sản xuất ở các khu công nghiệp cũng như các hoạt động sinh hoạt hàng ngày của người dân. Một dạng câu hỏi mở được đưa ra nhằm thu thập nhiều thông tin, nhiều đề xuất của người tham gia vào việc nâng cao chất lượng nguồn nước mặt trong thời gian tới. Kết quả nghiên cứu Bảng 5 cho thấy, có tổng cộng 13 giải pháp hoặc nhóm giải pháp được đưa ra. Trong đó, giải pháp được nhiều người trả lời quan tâm nhất là giải pháp về việc xây dựng hệ thống xử lý các chất thải và đồng thời cần kiểm soát chặt chẽ các hoạt động xả thải của các khu công nghiệp, đây là giải pháp có nhiều người đưa ra nhất với 47 trong 145 người được khảo sát (chiếm tỷ lệ $32,4 \%$ ). Tiếp theo là giải pháp về việc hạn chế sử dụng thuốc BVTV và phân hóa học trong quá trình sản xuất nông nghiệp (trồng lúa hoặc trồng cây ăn trái) với 45 ý kiến được đưa ra (chiếm tỷ lệ $31,0 \%$ số người được khảo sát). Giải pháp thứ ba trong việc cải thiện chất lượng nguồn nước mặt là cần nâng cao ý thức cho người dân bằng cách tổ chức các hoạt động tuyên truyền về môi trường, trong trường hợp nếu cần thì nên phạt nặng những tổ chức và cá nhân vi phạm với 39 đề xuất (chiếm tỷ lệ 26,9\%). Giải pháp được đề xuất thứ tư là cần xử lý rác đúng nơi quy định, khai thông cống rảnh và cần tích cực xử lý các nguồn nước bị bẩn (chiếm 20,7\%). Giải pháp thứ năm là các giải pháp về sử dụng các sản phẩm thân thiện với môi trường như sử dụng các sản phẩm tự hủy, hạn chế sử dụng bọc nilon và sử dụng các thiên địch trong sản xuất nông nghiệp thay vì sử dụng thuốc BVTV (chiếm tỷ lệ $14,5 \%$ ). Giải pháp thứ sáu về việc tận dụng các sản phẩm sau thu hoạch bằng cách trồng nấm rơm thay vì đốt đồng để hạn chế ô nhiễm môi trường (chiếm tỷ lệ 13,8\%). Giải pháp thứ bảy là thành lập các khu xử lý rác tập trung để dễ quản lý (chiếm 13,1\%). Giải pháp thứ tám là đề nghị Chính quyền địa phương và các cơ quan Trung ương hướng dẫn cụ thể việc cấp các quyết định thành lập các khu công nghiệp, các công ty và cần kiên quyết trong việc không phê duyệt các quyết định đối với các công ty, cơ sở sản xuất lạc hậu không đạt tiêu chuẩn (chiếm 11,7\%).

Ngoài ra còn bốn giải pháp và nhóm giải pháp về việc cải thiện chất lượng nguồn nước mặt cho địa bàn TPCT nhưng với tỷ lệ đề xuất thấp hơn $10 \%$ số người được khảo sát bao gồm: Giải pháp về dự báo các tác động xấu đến môi trường của con người nhằm sớm đưa ra các giải pháp giúp thay đổi quan điểm của người dân (chiếm $8,3 \%$ ); Giải pháp về quy hoạch tổng thể nguồn nước bao gồm cơ sở hạ tầng, đầu vào và đầu ra (chiếm $2,1 \%$ ) và hai giải pháp có tỷ lệ đề xuất $1 \%$ là nên trồng xen canh các loại cây trồng khác trong vườn cây ăn trái và nên sử dụng các hệ thống tưới thông minh nhằm tiết kiệm nguồn nước sử dụng và hạn chế được ô nhiễm nguồn nước thải ra môi trường. Kết hợp giữa thực tế kết quả quan trắc trong 20 năm giữa 04 khu vực hoạt động có ảnh hưởng đến chất lượng nước mặt, việc xây dựng các hệ thống xử lý nước thải tốt là một giải pháp giúp cải thiện môi trường tốt hơn trong tương lai vì nguồn ô nhiễm hữu cơ và vô cơ nhiều nhất ở khu vực dân cư, nơi mà khâu xử lý nguồn thải ít được quan tâm do các hoạt động riêng lẻ của các hộ gia đình.

Bảng 5. Các giải pháp cải thiện chất lượng nước mặt cho địa bàn TPCT.

\begin{tabular}{clcc}
\hline STT & \multicolumn{1}{c}{ Các loại giải pháp } & Tần số & Tỷ lệ (\%) \\
\hline 1 & $\begin{array}{l}\text { Xây dựng hệ thống xử lý chất thải và kiểm soát chặt các hoạt động của } \\
\text { các KCN }\end{array}$ & 47 & 32,4 \\
2 & Hạn chế sử dụng thuốc BVTV và phân hóa học & 45 & 31,0 \\
3 & $\begin{array}{l}\text { Nâng cao ý thức người dân, tuyên truyền cho người dân, phạt nặng các } \\
\text { tồ chức và cá nhân vi phạm }\end{array}$ & 39 & 26,9 \\
4 & Xả rác đúng chỗ, khai thông cống rảnh, tích cực xử lý nước bẩn & 30 & 20,7 \\
5 & $\begin{array}{l}\text { Sử dụng sản phẩm tự hủy, thân thiện môi trường, hạn chế bọc nilon, sử } \\
\text { dụng thiên địch }\end{array}$ & 21 & 14,5 \\
6 & Hạn chế đốt đồng và sử dụng rơm trồng nấm & 20 & 13,8 \\
7 & Thành lập các khu xử lý rác thải tập trung & 19 & 13,1 \\
\hline
\end{tabular}




\begin{tabular}{clcc}
\hline STT & \multicolumn{1}{c}{ Các loại giải pháp } & Tần số & Tỷ lệ (\%) \\
\hline 8 & $\begin{array}{l}\text { Nhà nước cần kiên quyết không phê duyệt các dự án sử dụng công nghệ } \\
\text { lạc hậu trong sản xuất }\end{array}$ & 17 & 11,7 \\
9 & $\begin{array}{l}\text { Trồng nhiều cây xanh, sử dụng xe buýt công cộng, sử dụng các phương } \\
\text { tiện giao thông thân thiện với môi trường }\end{array}$ & 13 & 9,0 \\
10 & $\begin{array}{l}\text { Dự báo các tác động xấu đến môi trường của người dân nhằm thay đổi } \\
\text { quan điểm }\end{array}$ & 12 & 8,3 \\
11 & Quy hoạch tổng thể nguồn nước & 3 & 2,1 \\
12 & Xen canh CAT và cây trồng khác & 1 & 0,7 \\
13 & Sử dụng hệ thống tưới thông minh & 1 & 0,7 \\
\hline
\end{tabular}

d) Đánh giá chất lượng nước mặt so với quá khứ

Kết quả khảo sát về đánh giá sự thay đổi chất lượng nước mặt so với trước kia cho thấy, đa phần người được khảo sát cho rằng chất lượng nước mặt hiện nay xấu hơn trước kia (chiếm tỷ lệ $63 \%$ trong tổng số người được khảo sát). Trong khi đó có $31 \%$ người được khảo sát cho rằng chất lượng nước không thay đổi so với các năm trước. Chỉ có số ít ( $6 \%$ người được khảo sát) cho rằng chất lượng nước mặt hiện nay tốt hơn trước kia (Hình 7).

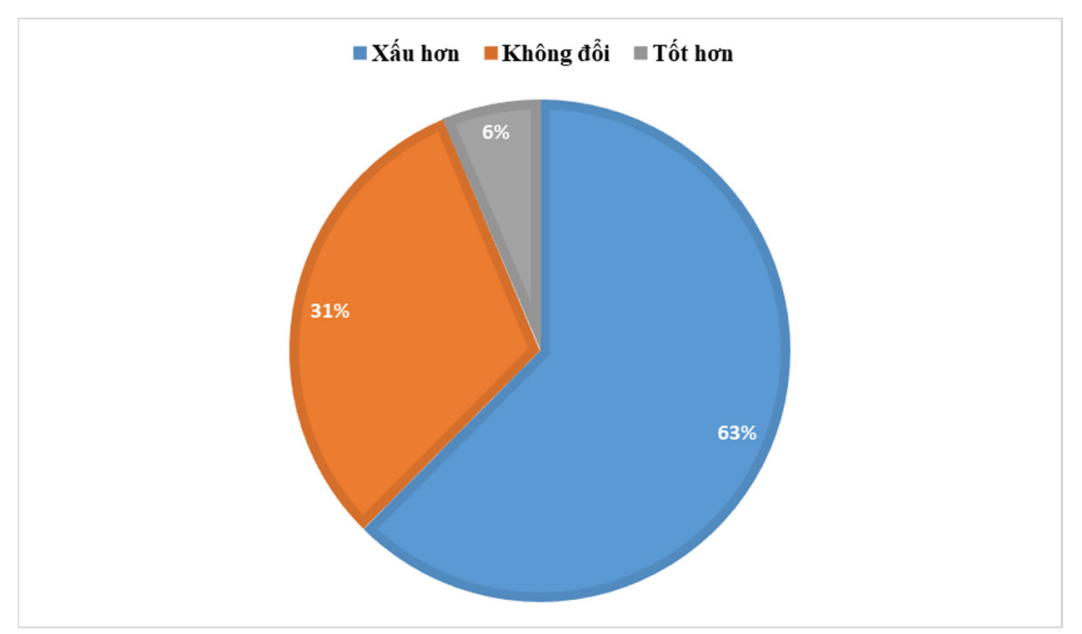

Hình 7. Đánh giá chất lượng nước mặt hiện nay so với trước kia.

e) Xác định các nguyên nhân làm ảnh hưởng đến nguồn nước mặt

Khi đánh giá chung về các lý do làm ảnh hưởng đến chất lượng nguồn nước mặt hiện nay so với trước kia, kết quả nghiên cứu Bảng 6 cho thấy do hiện nay xuất hiện rất nhiều công ty, xí nghiệp và khu công nghiệp, nhưng các đơn vị này xử lý chất thải chưa được tốt đã làm cho chất lượng nguồn nước ngày càng xấu hơn so với trước kia với 46 ý kiến (chiếm $31,7 \%$ trong tổng số người được khảo sát). Hai lý do quan trọng tiếp theo làm cho chất lượng nguồn nước bị giảm so với trước kia là người dân đã vứt rác thải xuống các con sông ngày càng nhiều $(17,2 \%)$ và thêm một phần do việc sử dụng quá nhiều phân bón và thuốc BVTV $(11,0 \%)$. Ngoài ra, còn một vài yếu tố khác được xác định như các rác thải sinh hoạt, ý thức tự giác của người dân không cao, sản xuất thâm canh tăng vụ, biến đổi khí hậu làm cho lũ ít và nhiễm mặn vào mùa khô, dân cư ngày càng đông và sử dụng không hợp lý các nguồn tài nguyên nước.

Bảng 6. Các lý do làm chất lượng môi trường nước hiện nay giảm.

\begin{tabular}{rlcc}
\hline STT & Lý do chất lượng nước & Tần số & Tỷ lệ (\%) \\
\hline 1 & Nhiều công ty, xí nghiệp, khu công nghiệp xử lý chất thải chưa tốt & 46 & 31,7 \\
2 & Rác thải xuống các con sông ngày càng nhiều & 25 & 17,2 \\
3 & Sử dựng quá nhiều phân hóa học, thuốc BVTV & 16 & 11,0 \\
4 & Nguồn nước thải sinh hoạt & 10 & 6,9 \\
5 & Ý thức người dân & 8 & 5,5 \\
\hline
\end{tabular}




\begin{tabular}{rlcc}
\hline STT & Lý do chất lượng nước & Tần số & Tỷ lệ (\%) \\
\hline 6 & Sản xuất lúa tăng vữ & 7 & 4,8 \\
7 & Khí hậu thay đồi, lư ít, nhiễm mặn & 6 & 4,1 \\
8 & Dân cư đông & 3 & 2,1 \\
9 & Sử dụng không hợp lý tài nguyên nước & 2 & 1,4 \\
\hline
\end{tabular}

Nhìn chung, kết quả đánh giá chất lượng nước mặt trong thời gian 20 năm từ 2000-2020 cho thấy chất lượng nước bị ảnh nghiêm trọng bởi các hoạt động của khu dân cư và khu công nghiệp. Tuy nhiên, kết quả khảo sát ý kiến của người dân thì có khuynh hướng ngược lại, người dân cho rằng nguồn nước bị ô nhiễm nhiều nhất do hoạt động của khu công nghiệp $(90,3 \%)$, kế đến là do hoạt động trồng lúa $(71 \%)$ và thấp nhất ở các hoạt động sinh hoạt $(53,8 \%)$. Nhưng thực tế kết quả quan trắc chất lượng nước mặt trong 20 năm cho thấy, các chất thải do hoạt động sinh hoạt của con người trong địa bàn TPCT là nguồn gây ô nhiễm nhiều nhất, tiếp theo là các chất thải từ các khu công nghiệp. Tóm lại, chất lượng nước hiện nay giảm hơn so với trước kia ở cả kết quả quan trắc thực tế và kết quả khảo sát người sinh sống trên địa bàn TPCT. Thông qua kết quả quan trắc và cảm nhận của người dân về nguyên nhân gây ô nhiễm, kết quả nghiên cứu này làm sáng tỏ một vấn đề là môi trường nước mặt bị ảnh hưởng nghiêm trọng hơn đối với các nguồn nước thải do sinh hoạt của con người thải ra đối với các chỉ tiêu $\mathrm{BOD}_{5}$ và $\mathrm{COD}$, nhưng cảm nhận của người dân là nước mặt bị ô nhiễm nhiều nhất do các hoạt động xả thải từ khu công nghiệp. Chính vì thế, cần tăng cường xử lý nguồn xả thải từ sinh hoạt trước khi hòa vào nguồn tiếp nhận là cấp thiết [22].

\section{Kết luận}

Giá trị $\mathrm{pH}$, nhiệt độ và $\mathrm{PO}_{4}{ }^{3-}$ không có sự khác biệt giữa 4 khu vực nghiên cứu. Tuy nhiên, các chỉ tiêu $\mathrm{BOD}_{5}, \mathrm{COD}$ và $\mathrm{TSS}, \mathrm{NH}_{4}{ }^{+}, \mathrm{Fe}, \mathrm{NO}_{2}{ }^{-}$và $\mathrm{NO}_{3}{ }^{-}$có sự khác biệt có ý nghĩa giữa các khu vực. Chất lượng nước mặt tốt nhất ở khu vực trồng cây ắn trái và có xu hướng xấu nhất ở khu vực dân cư. Hàm lượng amoni $\left(\mathrm{NH}_{4}{ }^{+}\right)$ở khu vực trồng cây ăn trái và khu vực trồng lúa đạt tiêu chuẩn về an toàn đối với sức khỏe con người, trong khi, khu dân cư và khu công nghiệp thì cao hơn so với quy định. Hàm lượng nitrit $\left(\mathrm{NO}_{2}{ }^{-}\right)$trong nước dao động từ 0,34-,7 mg/L, cao hơn khoảng 10-15 lần so với tiêu chuẩn. Chỉ số nitrat $\left(\mathrm{NO}_{3}{ }^{-}\right)$trung bình giữa $4 \mathrm{khu}$ vực nghiên cứu là $0,45 \mathrm{mg} / \mathrm{L}$, thấp hơn hai lần so với quy định. Chỉ tiêu hóa lý của nước ở 4 thời điểm lấy mẫu trong năm khác biệt không nhiều và có xu hướng xấu hơn ở tháng 12. Hàm lượng amoni và nitrat ổn định trong năm, trong đó hàm lượng amoni đạt cột B1 của QCVN 08-MT:2015/BTNMT. Hàm lượng nitrit vượt quy chuẩn cho phép, nhưng khuynh hướng cao nhất ở tháng 6 và sau đó giảm dần theo thời gian.

Kết quả khảo sát ý kiến người dân cho thấy chất lượng nước mặt bị ảnh hưởng nhiều nhất ở khu công nghiệp và các khu vực trồng lúa, tác động ảnh hưởng ít nhất ở khu vực dân cư. Chất lượng nước mặt bị ảnh hưởng do hiện nay có nhiều công ty, xí nghiệp, khu công nghiệp xử lý chất thải chưa được tốt. Các chất thải được thải trực tiếp xuống sông ngày càng nhiều và do sử dụng quá nhiều phân bón và thuốc BTVT. Kết quả cuối cùng là chất lượng nước hiện nay xấu hơn trước kia trong cả hai kết quả nghiên cứu từ số liệu thứ cấp chất lượng nước và đánh giá của cộng đồng dân cư. Nghiên cứu này cho thấy nguồn thải từ hoạt động sinh hoạt làm ảnh hưởng đến chất lượng nước mặt nhiều nhất, kế đến từ hoạt động của các khu công nghiệp, hoạt động trồng lúa là yếu tố gây ảnh hưởng thứ ba và hoạt động trồng cây ăn trái ít gây ảnh hưởng nhất. Tuy nhiên, nghiên cứu này chỉ tập trung phân tích các chỉ tiêu hóa lý nước, nhưng chưa phân tích các yếu tố về hàm lượng các kim loại nặng giữa các khu vực nghiên cứu.

Đóng góp của tác giả: Xây dựng ý tưởng nghiên cứu: N.T.T., T.Q.B., H.V.T.M.; Lựa chọn phương pháp nghiên cứu: N.T.T., T.Q.B., H.V.T.M.; Xử lý số liệu: N.T.T., T.Q.B., Lấy mẫu: N.T.T., T.Q.B., N.Đ.T.M.; Viết bản thảo bài báo: N.T.T., T.Q.B., H.V.T.M., N.Đ.T.M., N.T.T., B.T.B.L; Chỉnh sửa bài báo: N.T.T., T.Q.B., N.T.T., B.T.B.L., H.V.T.M. 
Lời cảm ơn: Cám ơn tại Trung tâm Quan trắc Tài nguyên và Môi trường - Sở Tài nguyên và Môi trường TPCT đã cung cấp số liệu quan trắc về chất lượng môi trường nước mặt tại Cần Thơ giai đoạn 2000 đến 2020. Cảm ơn các đáp viên đã tham gia vào việc đưa ra nhận xét về chất lượng môi trường nước tại Cần Thơ.

Lời cam đoan: Tập thể tác giả cam đoan bài báo này là công trình nghiên cứu của tập thể tác giả, chưa được công bố ở đâu, không được sao chép từ những nghiên cứu trước đây; không có sự tranh chấp lợi ích trong nhóm tác giả.

\section{Tài liệu tham khảo}

1. Bhuiyan, M.A.; Rakib, M.; Dampare, S.; Ganyaglo, S.; Suzuki, S. Surface water quality assessment in the central part of Bangladesh using multivariate analysis. KSCE J. Civ. Eng. 2011, 15, 995-1003. https://doi.org/10.1007/s12205-011-1079-y.

2. Simeonov, V.; Stratis, J.; Samara, C.; Zachariadis, G.; Voutsa, D.; Anthemidis, A.; Sofoniou, M.; Kouimtzis, Th. Assessment of the surface water quality in Northern Greece. Water Res. 2003, 37, 4119-4124. https://doi.org/10.1016/S00431354(03)00398-1.

3. Boyacioglu, H. Surface water quality assessment using factor analysis. Water Sa. 2006, 32, 389-393. https://doi.org/10.4314/wsa.v32i3.5264.

4. Poudel, D.; Lee, T.; Srinivasan, R.; Abbaspour, K.; Jeong, C. Assessment of seasonal and spatial variation of surface water quality, identification of factors associated with water quality variability, and the modeling of critical nonpoint source pollution areas in an agricultural watershed. J. Soil Water Conserv. 2013, 68, 155-171. https://doi.org/10.2489/jswc.68.3.155.

5. Zhang, W.; Li, H.; Sun, D.; Zhou, L. A statistical assessment of the impact of agricultural land use intensity on regional surface water quality at multiple scales. Int. J. Environ. Res. Public Health 2012, 9, 4170-4186.

6. Boyacioglu, H.; Boyacioglu, H. Surface water quality assessment by environmetric methods. Environ. Monit. Assess. 2007, 131, 371-376.

7. Minh, H.V.T.; Avtar, R.; Kumar, P.; Le, K.N.; Kurasaki, M.; Ty, T.V. Impact of Rice Intensification and Urbanization on Surface Water Quality in An Giang Using a Statistical Approach. Water 2020, 12, 1710.

8. Osibanjo, O.; Daso, A.P.; Gbadebo, A.M. The impact of industries on surface water quality of River Ona and River Alaro in Oluyole Industrial Estate, Ibadan, Nigeria. Afr. J. Biotechnol. 2011, 10, 696-702.

9. Teng, Y.; Yang, J.; Zuo, R.; Wang, J. Impact of urbanization and industrialization upon surface water quality: A pilot study of Panzhihua mining town. J. Earth Sci. 2011, 22, 658 .

10. Wang, J.; Da, L.; Song, K.; Li, B.L. Temporal variations of surface water quality in urban, suburban and rural areas during rapid urbanization in Shanghai, China. Environ. Pollut. 2008, 152, 387-393. https://doi.org/10.1016/j.envpol.2007.06.050.

11. Nguyệt, L.K. Vấn đề thực thi pháp luật về quản lý chất thải nguy hại ở Việt Nam hiện nay. Tạp chi Khoa hoc ĐHQGHN, Luật học 2011, 27, 126-133.

12. Trường, TV. Quản lý lưu vực sông thách thức và giải pháp. Hội đập lớn và Phát triển nguồn nước Việt Nam 2015, 1-12.

13. Dương, T.N. Đánh giá hiện trạng và phân tích diễn biến chất lượng nước mặt tỉnh Nghệ An. Luận văn Thạc sĩ Khoa học môi trường và bảo vệ môi trường - Đại học Quốc gia Hà Nội, 2012.

14. Trang, Đ.T.N. Sử dụng tiết kiệm tài nguyên nước ở một số quốc gia và bài học kinh nghiệm cho Việt Nam. Tạp chí Khoa học ĐHQGHN, Kinh tế và Kinh doanh 2014, 30(1), 72-772014. 
15. Tổng cục Môi trường Việt Nam. Quy Chuẩn Kỹ Thuật Quốc Gia về Nước Mặt QCVN 08-MT:2015/BTNMT. http://vea.gov.vn/quy-chuan (accessed on 6 April 2021). http://vea.gov.vn/Quy\%20chun\%20Vit\%20Nam/QCVN\%2008-MT-2015BTNMT.pdf (truy cập 02/10/2021).

16. Tổng cục Môi trường Việt Nam. Quy Chuẩn Kỹ Thuật Quốc Gia về Nước Mặt QCVN-

MT:2020/BTNMT.https://tailieuhoinghi.monre.gov.vn/Data/files/Du\%20thao_QC

VN\%20nuoc\%20mat\%20luc\%20dia.pdf (truy cập ngày 03/10/2021).

17. Thiện, H.Đ.; Biên, T.H. Vấn đề môi trường ở vùng kinh tế trọng điểm phía Namthực trạng và giải pháp. Tạp chí Khoa hoc ĐHSP TPHCM 2012, 35, 145-154.

18. Hưng, N.T.Q.; Mạnh, N.C.; Kỳ, N.M. Quan trắc, đánh giá hiện trạng chất lượng nước mặt kênh rạch tỉnh Bình Dương. Tạp chí Khoa hoc Thủy lợi và Môi truờng 2019, 66, 37-44.

19. Nga, B.T.; Thư, B.A. Chất lượng nước mặt và quản lý chất thải sinh hoạt tại kênh rạch bần thành phố cần Thơ Tạp chí Khoa học Trương Đại học Cần Tho 2005, 04, 26-35.

20. Giau, V.T.N.; Tuyen, P.T.B.; Trung, N.H. Đánh giá biến động chất lượng nước mặt sông cần thơ giai đoạn 2010-2014 bằng phương pháp tính toán chỉ số chất lượng nước (WQI). Tạp chi Khoa hoc Trương Đại hoc Cần Tho 2019, 105-113.

21. Minh, H.V.T.; Tâm, N.T.; Như, Đ.T.T.; Thành, N.T.; Tỷ, T.V. Đánh giá hiện trạng chất lượng nước mặt và hiệu quả mô hình canh tác lúa nếp ba vụ ở Bắc Vàm Nao, An Giang. Tạp chí Khi twợng Thủy văn 2021, 732, 38-48. https://doi.org/10.36335/VNJHM.2021(732).38-48.

22. Nguyen, T.G. Evaluating Surface Water Quality in Ninh Kieu District, Can Tho City, Vietnam. J. Appl. Sci. Environ. Manage. 2020, 24(9), 1599-1606. https://doi.org/10.4314/jasem.v24i9.18.

23. Giao, N.T. Evaluating current water quality monitoring system on Hau River, Mekong delta, Vietnam using multivariate statistical technique. Appl. Enviro. Res. 2020, 42(1), 14-25. https://doi.org/10.35762/AER.2020.42.1.2.

24. Ongley, E.D. Chapter 12: Water Quality of the Lower Mekong River. In: Campbell, I.C. (ed.): The Mekong: Biophysical Environment of an International River Basin, Academic Press, 4951 Connaught Ave., Montreal, QC, Canada H4V 1X4. 2009, 297-320. ISBN 978-0-12-374026-7. https://doi.org/10.1016/B978-0-12-3740267.00012-7.

25. Cát, L.V., Nhung, Đ.T.H., Cát N.N. Nước nuôi thuỷ sản chất lượng và giải pháp cải thiện chất lượng. Nhà xuất bản Khoa học và Kỹ thuật, Hà Nội. 2006, tr. 424.

26. Ly, N.H.T.; Giao, N.T. Surface water quality in canals in An Giang province, Viet Nam, from 2009 to 2016. J. Viet. Environ. 2018, 10(2), 113-119. https://doi.org/10.13141/jve.vol10.no2.pp113-119.

27. Tuấn, Đ.D.A.; Trung, N.H., Thư, B.A. Đánh giá hiện trạng nước mặt phục vụ khai thác cấp nước cho thành phố Sóc Trăng. Tạp chi khoa học Trường Đại học Cần Tho 2019, 4a, 61-70. https://doi.org/10.22144/ctu.jvn.2019.096.

28. Kazi, T.G.; Arain, M.B.; Jamali, M.K.; Jalbani, N.; Afridi, H.I.; Sarfraz, R.A.; Shah, A.Q. Assessment of water quality of polluted lake using multivariate statistical techniques: A case study. Ecotoxicol Environ. Saf. 2009, 72(20), 301-309. https://doi.org/10.1016/j.ecoenv.2008.02.024.

29. Mekong River Commission. Annual water quality data assessment report. MRC Technical Paper, 2015. 


\title{
Evaluating the surface water quality affected by activities in Can Tho City
}

Nguyen Thanh Tam ${ }^{*}$, Tran Ngo Quoc Bao², Huynh Vuong Thu Minh², Nguyen Truong Thanh $^{2}$, Bui Thi Bich Lien², Nguyen Dao Tuyet Minh ${ }^{1}$

${ }^{1}$ Mekong Delta Development Research Institute, Can Tho University; ngttam@ctu.edu.vn; minhB1811482@student.ctu.edu.vn

${ }^{2}$ College of Environment and Natural Resources, Can Tho University; hvtminh@ctu.edu.vn; ntthanh@ctu.edu.vn; btblien@ctu.edu.vn; baotran15101996@gmail.com

\begin{abstract}
The surface water is increasingly polluted due to natural hazards and human activities. Therefore, the monitoring, assessing, and controlling of surface water quality is a critical responsibility. This study was conducted to collect data on surface water quality from 2000 to 2020 and individual stakeholders were interviewed in the following affected areas: (i) residential area (Ninh Kieu district), (ii) industrial zone (Binh Thuy district), (iii) fruit area (Phong Dien district), and (iv) rice field area (O Mon, Thoi Lai, and Co Do district). The results show that sampling collection times were slightly different, but the surface water quality slightly decreased in December, for example, the $\mathrm{pH}$ and temperature had not differed among the 4 study areas. Surface water quality was the best in the fruit area, whereas it was the worst in the residential area. The surface water quality has decreased as a result of poor wastewater management by companies, and industrial parks. Stakeholders discharged the wastes directly into the river, and the fertilizers and pesticides were used excessively, therefore it is necessary to treat and manage the waste sources in the near future.
\end{abstract}

Keywords: Residential area; Industrial zone; Rice field area; Wastewater sources. 